\title{
CORPUS Corpus
}

Archivos virtuales de la alteridad americana

Vol 2, No $1 \mid 2012$

Enero / Junio 2012

\section{Una corte de caballeros para elNuevo Mundo: los proyectos (utópicos) de Gonzalo Fernández de Oviedo}

A court of knights for the New World: Gonzalo Fernández de Oviedo's (utopical) projects

\section{Vanina María Teglia}

\section{Journals}

\section{Electronic version}

URL: http://journals.openedition.org/corpusarchivos/1075

DOI: 10.4000/corpusarchivos. 1075

ISSN: $1853-8037$

\section{Publisher}

Diego Escolar

\section{Electronic reference}

Vanina María Teglia, « Una corte de caballeros para elNuevo Mundo: los proyectos (utópicos) de Gonzalo Fernández de Oviedo », Corpus [En línea], Vol 2, No 1 | 2012, Publicado el 30 junio 2012, consultado el 19 abril 2019. URL : http://journals.openedition.org/corpusarchivos/1075 ; DOI : 10.4000/corpusarchivos. 1075

This text was automatically generated on 19 April 2019 


\title{
Una corte de caballeros para elNuevo Mundo: los proyectos (utópicos) de Gonzalo Fernández de Oviedo
}

\author{
A court of knights for the New World: Gonzalo Fernández de Oviedo's (utopical) \\ projects
}

Vanina María Teglia

\section{EDITOR'S NOTE}

Fecha de recepción del original: 03/04/2012. Fecha de aceptación para publicación:

20/06/2012

\section{Introducción}

Una vez avanzada la Conquista en el Nuevo Mundo, para muchos la presencia de los españoles en América era ya una realidad evidente por sí misma; el "problema del indio" se convertía en el problema acerca de las formas posibles de relación de los españoles con los indios. Ante el destino incierto por aquellos años de las tierras "descubiertas" y también de España -recordemos la discutida ascensión al poder de Carlos I-, comienzan a surgir algunas propuestas de reforma del proceso de conquista y de colonización para el futuro del continente aún no develado en su totalidad. El que había sido nombrado Veedor del Oro de estas posesiones de ultramar y que será Cronista Oficial de las Indias por muchos años, Gonzalo Fernández de Oviedo (1478-1557), presenta un proyecto a la Corona española en el que el rey tendría mayor participación en la política de las Indias. Para eso, se llevarían allí hidalgos nombrados caballeros de la alta Orden militar de Santiago, que reemplazarían a los "codiciosos" encomenderos de "bajo linaje". Propone que emigre a las Indias toda una corte de hidalgos, nobles "caballeros de honra" y 
"limpios de pecado". En un primer lugar, y luego de haber estado setenta días en las Indias por primera vez, en 1519 pide que lo designen gobernador en Santa Marta en el Darién y, junto a esto, intenta este tan mentado traslado de caballeros.

2 En el medioevo, los nobles eran representados como caballeros del rey, es decir, como duplicaciones de la figura del monarca: un séquito que era elevado y reconocido al mismo tiempo que se asumía como réplica de esa máxima figura jerárquica no importa cuál fuese el rey en cada momento (Zumthor, 1994). La figura del caballero, ya sea vista en sus aspectos guerreros, heráldicos o cortesanos, cobra gran importancia en el siglo $\mathrm{XVI}^{1}$, tiempo en el que nuestro autor escribe su crónica. El mundo borgoñón del cual procedía el príncipe Carlos I tenía una alta valoración de la nobleza. Esto coincidió con el sentir español que acogió al joven príncipe. Varios e importantes han sido los estudios que se han ocupado de la figura y de los ideales del caballero en la conquista de América. Por citar sólo algunos: Los libros del conquistador (1996) de Irving Leonard, Orbe indiano (1998) de David Brading, Mesías, cruzadas, utopías (1997) de Jacques Lafaye, "La construcción cultural de la alteridad: el sujeto colonial y el discurso caballeresco" (1990) de Rolena Adorno, "Teoría literaria humanística y libros de caballerías" (2002) de Karl Kohut, entre otros.

Es nuestra hipótesis que, a pesar del erasmismo de estos años que criticaba duramente las "fábulas" de las novelas de caballerías², Oviedo, tanto en su proyecto de 1519 como en su Historia General y Natural de las Indias, considera que, lo mejor para "civilizar" a las Indias y "ordenar" el caos de aquellos primeros años del proceso conquistador es que el rey envíe caballeros castellanos a conquistar el Nuevo Mundo. Creemos que esta figura representa los ideales a los que adhiere fuertemente Oviedo: la pureza de sangre española, el linaje elevado y la lealtad al rey. Para esto, también circunscribe un anti-modelo que, de linaje bajo y desleal, proviene de la no deseada "mezcla de naciones y de sangre". El proyecto de nuestro autor es rechazado en dos oportunidades, por lo que después abandonará este tipo de propuestas. Nombrado Cronista Oficial de las Indias, traslada sus anhelos a lo que llamaremos propuestas utópicas implícitas en la superficie textual de la obra histórica, que se ven autorizadas por las particularidades propias del género, pero también por las retóricas de la época, que otorgaban gran importancia a la dimensión moralizante y doctrinaria de la Historia. Ciertos episodios narrados en la Historia General de Oviedo han sido constituidos por el ideal de la transposición de las formas de sociabilidad propias de la metrópoli española a las emergentes ciudades coloniales en Indias. Ya en la Segunda y Tercera Partes de esta Historia, reconocemos la emergencia de los dispositivos de lo que será la ciudad colonial americana. Como se verá más adelante, estos son los ideales de ciudad controlada, disciplinada y excluyente de la diversidad en favor de una distinción social demarcada por límites explícitamente geográficos. El relato en primera persona de la experiencia de Oviedo como gobernador de la ciudad de Santa María del Darién es sustancial al respecto. Velando por los intereses del imperio en las "lejanas" tierras de las Indias, el madrileño propone la concreción de una ciudad controlada por un sistema de castigos estricto y excluyente de la otredad indígena. Este recinto utópicamente cerrado expulsaría toda posibilidad de cruce y mestizaje público con el nativo americano. Impondría justicia por medio del castigo ejemplar y de manera homogénea. 


\section{Una propuesta medieval de reforma y evasión}

4 El proyecto reformista de Oviedo de 1519 sólo puede leerse hoy en día del resumen que este compendió en el capítulo séptimo de la Segunda Parte de su Historia General. Estos pocos párrafos no fueron publicados en vida del autor, ni fray Bartolomé de Las Casas (1474-1566) ni Francisco López de Gómara (1511-1566) comentaron el episodio y, a pesar de que su autor lo presenta más de una vez -en 1519 y 1524 por lo menos-, no hemos localizado las capitulaciones correspondientes en el Archivo General de Indias. Dos cosas llaman primero la atención: que la sección se presente bastante resumida -lo que es poco común en la verbosidad oviedana- y que el autor aluda a sí mismo como enunciador y actor de los hechos en primera persona, pero luego inmediatamente en tercera. Transcribimos parcialmente el relato:

Tornando a la historia, digo que me hallé en la corte del Emperador Rey, rey de Romanos e futuro Emperador, el año de mil e quinientos e diez y nueve, en la cibdad de Barcelona, que había ido destas partes a dar relación a Su Majestad de cosas que convenían a su Real servicio, en nombre de la cibdad de Sancta María del Darién, cabeza de Castilla del Oro, y vi que tres hombres que en estas partes querían servir a Sus Majestades en estos cargos de capitanes, pidieron tres gobernaciones. El uno demandó a Sancta Marta, y concediósele; pero al tiempo del capitular, entre otras cosas suplicó que se le concediesen cient hábitos de Sanctiago para cient hombres hijosdalgos en quien concurriesen la limpieza del linaje e las otras calidades con que se suele admitir este hábito militar a quien su Majestad quiere honrar y hacer merced. E concediósele cuanto pidió, excepto esta orden de caballeros que pedía, porque a algunos del Consejo de Su Majestad les paresció que era inconveniente, e que la Orden se podría hacer muy poderosa con el tiempo en estas partes, o mejor diciendo, no fue la voluntad de Dios que se hiciese.

Pero acuérdome que, preguntando al que esto pedía la causa por qué demandaba estos hábitos, dijo que porque le parescía único remedio e manera mejor que todas para ser gobernada e poblada la tierra, y en más breve tiempo, y los indios mejor tractados y antes convertidos e bien industriados que por otra vía alguna de cuantas se habían intentado por otros gobernadores; y que pensaba tener esta forma en ello: que los indios que se encomendasen fuesen caciques señalados, con su tierra, por encomienda de un comendador caballero de la Orden, e por los días de su vida; e que muerto aquel caballero, el comendador mayor deste convento los proveyese a otros; e que estos comendadores estuviesen debajo de la gobernación e administración de este comendador mayor e gobernador, e que este superior no tuviese encomienda de indios más del hábito, e su encomienda fuese el salario que su Majestad diese a los gobernadores, e aquel Emperador nuestro señor proveyese como administrador perpetuo, cuando vacase la tal encomienda mayor e oficio de gobernación, a quien fuese servido. Pero que aquéste, en la provisión de las vacantes de las tales encomiendas de indios, lo hiciese conformándose con los votos de los más caballeros de la Orden, que presentes se hallasen. Siguiérase de esto que los indios fueran muy bien tractados e convertidos a la fe, y la tierra muy bien poblada de hombres de honra e de buena casta que, con esperanza de estos hábitos e beneficios, fueran a vivir en aquella provincia. Excusáranse cosas que en aquellas tierras han subcedido de que aquí se tractará en el presente libro, si Dios fuera servido que esta Orden allí tuviera un convento. Pero como todo esté debajo de la mano y determinación de Dios, eso se tenga por mejor que él permite que haya efeto, pues que en esto no lo hobo. De manera que, negándole esta Orden militar e hábitos al que lo pidió, no quiso entender más en ello, e creo yo que pues el Consejo de su Majestad en ello no vino, que algunas causas justas le moverían que yo no alcanzo. 
Otro pedía la isla de la Trinidad, de quien se ha tratado en el libro precedente, e díjose una vez que se la habían concedido; pero porque era persona sospechosa e que se dubdó que pudiese cumplir lo que prometía, le echaron por vano.

El tercero no quería sino labradores simples, e hacerlos caballeros e darles hábitos de unas cruces que en algo querían parescer a las de la Orden de Calatrava; y éste dijo más fábulas y prometió más cosas, e halló más favor, y salió con la merced que pidió, e hizo gastar muchos dineros a Su Majestad. Pero no cumplió cosa alguna de cuanto ofreció de hacer. Y éste ya se dijo quién era, cuando se tractó de la isla de Cubagua en el libro XIX de la primera parte destas historias. (...) (L 26, c 1 [PT III, p. 62])

5 Desconocemos al que pide la isla de la Trinidad, pero, el que quería labradores simples para hacerlos caballeros de Calatrava y que, con esto, luego "hace perder muchos dineros" a la Corona será su mayor contrincante, el fraile dominico Bartolomé de las Casas. El que demanda la gobernación de Santa Marta junto con los hábitos de la Orden de Santiago es el mismo autor de la crónica, Fernández de Oviedo. Es un proyecto de reforma ordenadora de las conquistas. Intenta adaptar las prácticas de este proceso y la expansión española a la situación compleja y desordenada de las Indias, que precisaba que los indios fueran preservados - lo mismo que la tierra- y convertidos para ser "bien industriados". Para continuar con el aprovechamiento de la tierra y de los nativos -base de la satisfacción de las necesidades del imperio- era necesario instalar el orden y mantener a aquellos con vida. Oviedo debió haber llegado a la conclusión de que las Indias requerían, en verdad, para su conquista y colonización, "caballeros virtuosos": esto es, hidalgos limpios de sangre, de virtudes probadas y "otras calidades" como éstas, elevados a nobles distinguidos. No más hombres codiciosos y faltos de virtud en el Nuevo Mundo.

Esta elección, además, tiene un tinte utópico en el pensamiento aún medieval de Oviedo. La figura del caballero era un elemento ordenador en la fantasía de los hombres de los siglos XII y XIII. "Como una instancia de mediación entre la apariencia caótica del mundo social y un orden deseado, el caballero es a un tiempo improbable y poderosamente evocador" plantea Paul Zumthor (1994, p. 195). En la Edad Media, esta figura controlaba el espacio, surcaba los territorios más alejados y los "convertía" en conocidos y accesibles. Además, aseguraba el alcance de la justicia a esos espacios remotos. Si bien entre 1300 y 1500 la caballería había perdido progresivamente su importancia militar, la época dio nuevo vigor a la figura del caballero y se depositaron en él algunas esperanzas. Las razones provinieron del hecho de que las tierras nuevas cruzando el Atlántico estimularon el deseo de aventura. Además, a principios del siglo XVI, se publica el Amadís de Gaula (la edición más antigua conocida es de Zaragoza, 1508) con gran éxito editorial, lo que multiplicó el conocimiento de las particularidades de la literatura de caballerías entre los hombres de todos los estratos sociales, incluso entre los enviados a las Indias ${ }^{3}$. Como plantea Zumthor: "La figura del caballero andante cumple la función de un sueño compensatorio, animado por un deseo de integración del Otro y de lo desconocido por la virtud de la caballería" (1994, p. 198). Suscita la fantasía de que, por su entereza, el caballero puede cruzar la frontera de lo desconocido y capturar y vencer al Otro. Su acción es cristianizadora. Por esto también, a nivel simbólico y utópico o mítico, el caballero para Oviedo es el personaje de su época más apropiado para someter al Otro amerindio en más breve tiempo. Es concebido como duplicación del rey: "A través de los caballeros, a los que concede permiso para errar, el rey se enfrenta de forma figurada al universo" (Zumthor, 1994, p. 202). Con el correr de los años, la literatura de caballerías se transformará en una fantasía evasiva para los lectores de las cortes. 
7 Frente al caos de la Conquista por aquellos años, sobre todo en las Antillas y en la parte centroamericana de la Tierra Firme, y para los extensos y promisorios ámbitos desconocidos, Oviedo desea el control que podrían traer los caballeros. Es justamente en 1519, que también él mismo publica el Claribalte ${ }^{4}$, novela de caballerías considerada la primera escrita en América. Oviedo se encuentra, en ciertos aspectos, inmerso en el debate sobre el sentido de la nobleza. Así, imagina una "verdadera" utopía "necesaria" para sofocar la anarquía que finalmente redunda en las continuas muertes de los esclavos útiles al imperio y en el alzamiento y desobediencia de algunos capitanes y gobernadores. "Siguiérase de esto [es decir, del proyecto utópico concretado] que los indios fueran muy bien tractados e convertidos a la fe, y la tierra muy bien poblada de hombres de honra". Esta imagen utópica y deseada que pertenece a Oviedo -que podría muy bien aparecer también en la escritura de Las Casas- se contrapone a la verdadera "Cucaña" ${ }^{5}$ de los españoles en Indias que el Cronista Oficial describe, por ejemplo, unas páginas después:

Oyéndose llamar Vuestra Señoría e Magníficos, embelesados, levantados en el aire, e trocando el seso, escuchando lagoteros e hambrientos soldados, dan con el juicio al través, e ofrecen sus personas a lo que no pueden bastar sus fuerzas; e poniendo las ánimas en condición, hacen unos fines que ningún cuerdo los puede haber envidia sino lástima. (...) y si Dios los pone en estas partes o Indias, miren que no sea tanto en buscar riquezas mal habidas e bañadas en sangre humana, como en convertir e procurar la salvación destos tristes indios (Oviedo, L 35, proemio [PT IV, p. 285-286])

La acumulación metafórica del primer párrafo - “embelesados, levantados en el aire, e trocando el seso, escuchando lagoteros e hambrientos soldados"- aparece comúnmente en los proemios a los libros de la Historia General de Oviedo, allí es donde el cronista da rienda suelta a la interpretación alegórica y a las generalizaciones. Sumado a esto, el párrafo tiene un tono indiscutiblemente moralizador y amonestador de la codicia y la soberbia. El pedido de Oviedo de 1519 a la Corona intenta borrar del mapa de las Indias a los posibles tiranos y traidores a la Corona como los que describe en el párrafo, y contener y moderar la expoliación y la voracidad.

\section{Limpieza de sangre y de linaje: los caballeros de Sanctiago entre amerindios}

9 Oviedo solicita que se elijan cien hijosdalgos para ser investidos con los hábitos de la Orden de Santiago. Esta orden religiosa y militar se había conformado en el siglo XII y, en su origen, sus caballeros protegían de los moros a los devotos peregrinos en el Camino del apóstol Santiago ${ }^{6}$. El tema de la pelea contra los musulmanes es una de las razones inspiradoras de la Orden, subrayada incluso en su Regla de 1529. Estos caballeros participaron de todas las guerras de la Reconquista. Simbólicamente, contribuyeron con la lucha contra la infidelidad en defensa de los fieles y de su integridad religiosa. Que Oviedo requiera caballeros de esta alta orden religiosa y militar para las Indias en parte expresa su concepción de la Conquista como guerra española contra la infidelidad y el infiel del Nuevo Mundo.

Los fundadores de aquella Orden habían sido condes y hombres ricos de España. Según cuenta la Regla, antiguamente eran: "varones nobles por linage, y sabios en las cosas del mundo, claros en el ejercicio de las armas", pero "abastados de los bienes temporales, y dotados de toda bienaventuranza mundanal". En aquellos tiempos, vivían en pecado: eran 
codiciosos y viciosos hasta que, "por gracia de Dios", se convirtieron en Caballeros de Jesucristo. Luego de esta "conversión", comenzaron a alimentar las virtudes de la austeridad, la humildad, la templanza de ánimos y la prudencia. Esta última, de tradición platónica, es la condición más apreciada por Oviedo, quien la observa sólo en algunos capitanes que se desempeñaron en las Indias. Aparece, por otra parte, como sentencia en la iconografía imperial y acompaña los emblemas de los Austrias ${ }^{7}$. Otra ventaja que debe haber convencido a Oviedo para elegir la Orden es el hecho de que estos caballeros tenían encomiendas antiguamente, algunas como resultado de sus victorias en las Guerras de la Reconquista. Podría haber elegido otras órdenes de caballeros para distinguir a los enviados a las Indias, como la de Alcántara o la de Calatrava, de la que tiene una muy alta estima. Pero estas dos exigían castidad a sus integrantes y abstención de los "placeres carnales". La de Santiago, en cambio, era flexible en este sentido y permitía el casamiento y el placer dentro de la fidelidad matrimonial. Oviedo mismo, en correspondencia con esta licencia, otorga un rol importante en la Conquista a las mujeres españolas casadas legítimamente con capitanes, gobernadores y soldados que van a las Indias. Él mismo lleva a la suya propia a vivir a la indeseable tierra del Darién. Prefiere la fidelidad y el matrimonio al "hacerse de mancebas" indias como los demás "pecadores".

11 Otra razón se explica en circunstancias personales de los años previos a 1519. A poco de regresar a España de una breve estadía en las Indias, la muerte de Fernando el Católico lo decide a llevar sus memoriales de protesta contra Pedrarias Dávila ante el joven príncipe Carlos V, quien se hallaba en Flandes y todavía no conocía España. La ida desde Madrid hasta Flandes le costó a Oviedo cuatro meses y muchos dineros. No solamente eso, en el camino le suceden algunos de sus padecimientos "favoritos", recurrentes en su relato, como los naufragios y las aflicciones propias de las Vidas de Santos: pasa extrema hambre -mayor que en las Indias, declara - en una isla cercana a Inglaterra y, previamente, la embarcación sufre los estragos de una tormenta grandísima e impredecible que la desvía hacia atrás, hacia la Coruña. Luego: "desde allí fuimos en romería algunos a visitar la casa del Apóstol glorioso Sanctiago" (L 24, c 11 [PT III, p. 250]). Esta peregrinación al patrono de España -más tarde, también patrono del imperio- sucede precisamente unos meses antes de que Oviedo llegase a la corte extranjera de los flamencos, que finalmente poca importancia dio a sus reclamos. Algunos años después se decide a presentar su proyecto al rey. La cualidad castiza del apóstol Santiago, las circunstancias de recambio de un gobierno español que había conseguido unificar los reinos hispánicos en uno que fue sentido como extranjero por varios españoles, y el pensamiento todavía medieval de Oviedo muy creyente de la Providencia Divina determinaron los pedidos de "hidalguía" y "nobleza" de la Orden de caballeros de Santiago para su proyecto de 1519.

Los cien hombres hijosdalgos requeridos debían estar "limpios de sangre". Este tema y su correlativo - la pasión social por la genealogía - tienen una larga trayectoria en España. Oviedo es uno de sus mayores partidarios a lo largo de su vida. Pasado un tiempo, en sus últimos días, incluso aprobará el decreto de limpieza de sangre promulgado por el arzobispo de Toledo. Es probable que nuestro autor esté interesado en la Orden de Santiago también porque las "sanctas e loables constituciones de las órdenes militares de Santiago, Calatraua e Alcántara no admiten cauallero al hábito que sea de estirpe de judíos" (Oviedo, 1974, p. 126). Esta explicación aparece en sus Quinquagenas de la nobleza española, escritas casi al final de su vida en la fortaleza de Santo Domingo de La Española y al poco tiempo de haber terminado la redacción de la Segunda y Tercera partes de su Historia. Es decir, a Oviedo le interesa imponer un criterio de selección para las Indias: que 
no a cualquiera le sea dado poder ir, algo que por otra parte debió aprender de su experiencia como Secretario de la Inquisición en 1506. Una primera exclusión de su proyecto podría recaer, de esta manera, sobre los judíos que, desde antes del reinado de los Reyes Católicos, venían siendo marginados en aumento y condenados violentamente a lo largo de los siglos XVI y XVII.

Para J. H. Elliot (1969), la Inquisición - como tribunal dedicado a imponer la ortodoxia religiosa-, acompañada y antecedida por prácticas generalizadas que sancionaban toda desviación de las normas, fue en gran medida la causante de un clima de desconfianza y sospechas mutuas que finalmente redundó en la obsesión por la pureza de la fe y luego de la raza. Hay también una hipótesis de Américo Castro que sostiene que la preocupación por la limpieza de sangre fue enarbolada en sus orígenes por el "judío minoritario" resentido con su antigua casta ${ }^{8}$. Había en este un anhelo de "elevarse" y diferenciarse de los que formaban parte del sector social del que él mismo se había separado recientemente. Este mismo deseo es quizás también el que pudo haber abrigado un pequeño hidalgo como Gonzalo Fernández de Oviedo, pero proyectado sobre los "simples", los faltos de títulos de nobleza, los judíos y los extranjeros9. Es, del mismo modo, lo que lleva a hidalgos de poca distinción como Hernán Cortés, Pedrarias Dávila y los Pizarros, entre muchísimos otros, a buscar hacerse ricos y notables a expensas de la conquista y el saqueo en las Indias. Buscaban ascenso y distinción. Notemos que el pedido de Oviedo a la corona de los hábitos de Santiago para hidalgos no se refiere a limpieza de "sangre" sino a limpieza del "linaje": "suplicó que se le concediesen cient hábitos de Sanctiago para cient hombres hijosdalgo en quien concurriesen la limpieza del linaje e las otras calidades con que se suele admitir este hábito". Así, las conquistas de las Indias serían parte de una afición honrosa alejada de profesiones degradantes, como la actividad mercantil y aún más innoble labor de la agricultura ${ }^{10}$. Para Américo Castro: "el honorreputación nacional era confundido con el del individuo, y se consideraba un baldón colectivo el que un solo español incurriera en herejía. (...) Ley, religión, moral y entrelace colectivo venían entonces a ser una y la misma cosa." (1984, p. 3). El español del siglo XVI confundía el honor-reputación del individuo -su pureza de sangre y de herejía- con el de la nación, reino o familia.

El deseo en Oviedo de "pureza" castellana e hidalga entre los hombres líderes en el Nuevo Mundo se convierte en desprecio por las otras naciones "intrusas" de la Conquista:

E los que por falta de habilidad, no pueden o no saben contrahacer nuestro romance, é trompezando en lo que dicen se conoce, e claro, que son portugueses, llámanse flamencos, e los suizos alemanes, e los italianos dícense sicilianos o na politanos. En fin, dando a entender a quien no los entiende, que son de los señoríos de César, pasan como nosotros. Pues griegos e levantiscos e de otras naciones son incontables. (L 29, c 34 [PT III, p. 355], el resaltado me pertenece).

Así como Fray Bartolomé de Las Casas ve en los pecados de los españoles la causa de que las Indias se destruyan y profetiza el posterior castigo en el más allá de conquistadores y encomenderos, en Oviedo la culpa de la destrucción de las Indias recae sobre los pecados de los mismos indios - canibalismo, sodomía, idolatría-, sobre algunos capitanes codiciosos y también sobre las "mixturas" de linajes y naciones (L 29, c 34 [PT III, p. 355]): "mezclas apartadas del rebaño patriçio" (Oviedo, 1974, p. 207). Aborrece la mezcla y el mestizaje. A esto responde su adhesión a la fidelidad matrimonial que vimos más arriba: el "juntarse con mancebas" es justamente otra mezcla nueva, ahora con nativas del Nuevo Mundo. La sociedad ideal imaginada por el cronista e implícita en sus escritos coloca a los indios en el lugar de vasallos sometidos y a los castellanos, en el poder. Estas son, entre 
otras, las condiciones que cree necesarias para que la Conquista continúe un desarrollo ordenado de gobierno y población. Nuestro Cronista Oficial responde, en el ámbito particular de las Indias, a las discriminaciones impuestas por los estatutos de limpieza de sangre que proliferaban por aquellos años y se distancia, en cambio, del erasmismo de la época, cuyo antecedente en España son los tratados de los conversos impresos en el siglo XV (Sicroff, 1982). Estos procuraban acallar la voz de los promotores de los estatutos discriminatorios y perfeccionar el cristianismo en sus valores espiritualistas y austeros. A principios del siglo XVI, tal como estos tratados, el erasmismo español impone la búsqueda generalizada de armonía y de paz entre los reinos fieles al cristianismo ${ }^{11}$. Existía, en España, la pulsión a combatir unos ideales de convivencia pacífica y armónica entre diversos fieles: cristianos viejos y conversos judíos, conversos musulmanes y de otras naciones incorporadas luego al imperio español y a la fe cristiana.

En la preocupación oviedana por la preservación de la pureza de sangre de los castellanos, deben haber influido, entre otras, las necesidades de conservar distinciones y privilegios perseguidas, en ese entonces, por todos los grupos con cierta herencia nobiliaria, que se autojustificaban en muchas ocasiones en la metáfora paulina de la diversidad de los miembros de una sociedad (Sicroff, 1982). Deben haber pesado, además, algunas expectativas que desde su primer viaje a las Indias el cronista comenzó a formularse al integrar la armada de Pedrarias Dávila que zarpó en 1514. Casualmente y un poco excepcionalmente para la época, esa armada estuvo constituida por distinguidos hidalgos: "y ésta fue una de la más hermosa gente y escogida que ha pasado a estas Indias" (L 29, c 6 [PT III, p. 222]). En ella viajaban Bernal Díaz del Castillo, Juan Ponce de León, Francisco Pizarro, Diego de Almagro y Hernando de Soto ${ }^{12}$. Albert Sicroff (1977) y también Américo Castro, en sus últimos años de estudios (1984), consideran que, en estos años de "pureza de sangre y de linaje" en España: "se volvió endémica la necesidad de arrojar del país o de exterminar a quienes disentían de lo creído y querido por los más poderosos" (Sicroff, 1977, p. 118).

Oviedo anhela la monopolización castellana sobre las distinciones y los ascensos nobiliarios obtenidos a través de los servicios prestados en las Indias. Antonello Gerbi (1978) ha visto también el rechazo a la progresiva liberalidad de la política inmigratoria de España, que no limitaba la posesión de las Indias a los castellanos en los primeros escritos del Cronista Oficial. El crítico italiano cita estas palabras de Oviedo: "comoquiera que aquéllos [los castellanos] fueron los que las Indias descubrieron, e no aragoneses, ni catalanes, ni valençianos, o vasallos del patrimonio real del Rey Cathólico" (1978, p. 389). Por lo visto, sin embargo, no fue únicamente en sus primeros años el rechazo de nuestro autor a este tipo de apertura. Por otra parte, Oviedo olvida que no fue precisamente un castellano el que descubrió las Indias. Pero, más allá de esto, ya en 1519 rechazaba lo que se convertiría en tópico: el monopolio sevillano-gaditano de relaciones y comercio con América. Considera que, siendo él castellano "original de Madrid", tenía entre sus manos $-o$, mejor dicho, en su "sangre"- una carta de derechos irrefutables y más poderosos para gobernar y dirigir, junto a otros castellanos, la población y el sometimiento de los reinos indianos. La necesidad de pureza del idioma castellano, por ejemplo, elegido para su Historia en reemplazo del latín participa, del mismo modo, de su procuración por la deseada "limpieza" de linaje ${ }^{13}$. 


\section{Una sociedad ideal de jerarquías y encomiendas}

18 En última instancia, Oviedo quiere imponer, sobre el espacio desconocido y aparentemente sin orden de las Indias, un sistema de control jerárquico cuyo último garante sea el rey mismo. El proyecto de cien caballeros continuaría el vínculo con los nativos establecido por la encomienda, pero con algunas variaciones. Los encomendados serían los caciques, y sus tierras dependerían de uno de los caballeros de la Orden tanto tiempo como viviese este caballero. Estos, a su vez, estarían bajo las órdenes de un gobernador mayor que no tendría encomiendas de indios y que viviría del salario que le diese su Majestad. El Emperador sería el administrador y proveedor perpetuo de caballeros y último garante sostenedor de todas estas encomiendas. Sin embargo, las decisiones del monarca español respecto de las suplencias de vacantes en Indias estarían sujetas a la aprobación de la mayoría de los caballeros de la Orden en Indias. Se trataría de un sistema de gobierno cuya racionalidad descansaría en la necesidad de las jerarquías, tanto de los caballeros de la Orden de Santiago como de los mismos caciques reconocidos por los indios. Oviedo no niega que los indios puedan gobernarse a sí mismos, por esto su proyecto respeta la jerarquía indígena. Contempla -al menos en este momento y para su propósito- el Derecho Natural de Gobierno, herencia aragonesa del tomismo que defiende el poder de los gobernantes nativos, aún sometidos a la corona castellana. Como en la España de los Reyes Católicos, Oviedo tenía en mente en esta instancia la idea de un Imperio plural, cuyos estados sometidos conservarían sin embargo sus particularidades y modos de vínculos sociales. Finalmente, las virtudes nobles encarnadas en todos los caballeros garantizarían la ética del gobierno, el fin de las competencias entre los conquistadores y la conservación de los vasallos indios.

El sistema jerárquico esbozado por Oviedo dentro de su sociedad ideal tiene su fundamento en la idea extendida de justicia distributiva de Santo Tomás, basada a su vez en los conceptos de igualdad y diferencia entre ciudadanos de la "ciudad ideal" fijados por la Política de Aristóteles ${ }^{14}$. Aquella justicia, definida por el autor de la Suma Teológica, es la que rige justamente las relaciones de subordinación en lo social y la que, de cumplirse, distingue el buen gobierno del malo: "El acto de justicia es el dar a cada uno lo suyo (...) se determina el término medio atendiendo a la diversa dignidad de las personas" (Tomás de Aquino, 2000, p. 350 y 352). Los bienes comunes -entiéndase por esto también los cargos públicos y la administración- se deben distribuir en proporción a los méritos, "dignidades" y necesidades de las personas. Así como el caballero tiene la virtud de mandar, el vasallo tiene la necesidad de servir. La sociedad oviedana, a diferencia de lo que planearán las órdenes de frailes mendicantes para América, da "a cada uno lo suyo". Es finalmente una estrategia de inclusión diferencial de los amerindios al proyecto de la metrópoli, como dispositivo fundamental de la dinámica imperial. Sin embargo, no presenta jerarquías al nivel de los hidalgos ordenados caballeros. Allí hay igualdad de condiciones y de decisión. El voto del rey, aunque sí de mayor peso, debe sujetarse a la evaluación de esta Junta de Señores. En ella, todos son considerados en igualdad de "dignidades" y méritos. Hay, en esto, una idea de hermandad de los poderosos de alto linaje y de virtudes caballerescas.

20 El sistema de Oviedo reforzaría la encomienda de indios que, ya para 1519, se hallaba semi-institucionalizada. Siguiendo el itinerario descripto por Lewis Hanke en La lucha por la justicia en la conquista de América (1949), se observa que la Corona tuvo una posición 
fluctuante a lo largo de los años respecto de esta institución intermediaria que cuidaba de la hacienda y del tributo pagado a los reyes. Las posiciones enfrentadas, es decir, la polémica constante, fue la marca que persistió en todos los escritos aparecidos en estos años ${ }^{15}$. Las primeras, organizadas por Cristóbal Colón en 1499, según cuenta Bartolomé de las Casas en el Octavo Remedio, fueron inmediatamente revocadas por Isabel la Católica. En 1495, los Reyes Católicos habían reunido a una junta de teólogos y letrados que decidieron a conciencia si una posible política esclavizadora era legítima. Según el resumen recogido por Rolena Adorno: "La junta resolvió que los indios eran libres y que no se podían vender, excepto los habidos de una guerra justa" (1992, p. 48). Nadie debía "encargar" a nadie los vasallos directos de la reina. A pesar de esto, en el mismo año de 1499 y por causa de una sublevación indígena en la Española, Colón instituyó un nuevo repartimiento que, si bien al momento no fue aprobado por los Reyes, finalmente en 1504 fue aceptado de hecho. De esta manera, continuaron las vacilaciones de los monarcas respecto del tema. La cuestión atravesó las tibias restricciones impuestas por las leyes de Burgos, que pretendieron suavizar la carga de los indios y considerarlos hombres libres, aunque sin suprimir el sistema de los repartimientos (Zavala, 1935, p. 45). Poco cumplimentadas en Indias ciertamente, luego estas leyes fueron abolidas en 1519 en una capitulación firmada en la Coruña.

Con Carlos V, llegaron los años en que más osciló la cuestión de la encomienda indígena. Este rey llegó a tomar medidas contradictorias en la década de 1540, momento en que la encomienda llegó a ser una forma de premio por servicio al emperador (Adorno, 1992, p. 49). En 1542, el monarca aprueba las Leyes Nuevas. Son los años en que Oviedo se encuentra escribiendo y corrigiendo la Segunda y Tercera partes de su Historia ${ }^{16}$. Llamativamente, su pedido a la corona de los cien caballeros de Santiago en 1519 tiene gran similitud con algunas disposiciones de estas leyes. Estas prohíben hacer esclavos a los nativos y solo autorizan las encomiendas al que posea título aprobado. Niegan esta institución a aquellos que la hayan obtenido en las revueltas anárquicas de Pizarro y Almagro en Perú. Tampoco podían tener encomiendas los funcionarios y los prelados. Su posesión prescribía con la muerte del encomendero, luego sus indios y sus descendientes debían quedar libres. Las reacciones en contra fueron varias ${ }^{17}$, tanto en las Indias como en España y ejercieron tanta presión que, en 1545, Carlos $\mathrm{V}$ revocó las disposiciones más molestas para los encomenderos. La razón de muchos para esta deposición, incluso de varios prelados, era la misma que había aducido Colón en 1499: las encomiendas eran un dique de contención contra las rebeliones de los indios, de lo contrario, estos se levantarían contra los españoles y el rey.

En 1546, finalmente, la Corona, luego de todo este proceso, decide continuar con las encomiendas hereditarias y revocar la disposición que liberaba a los indios encomendados en las luchas entre Pizarro y Almagro. Grandes festejos se organizaron en la ciudad de México por la derogación de las Leyes Nuevas. El 26 de diciembre de 1546 se decretó día festivo para celebrar el triunfo de la continuación del sistema:

Se organizaron bailes según el estilo caballeresco antiguo, y se autorizaba al mayordomo de la población a que comprara las vestiduras necesarias para cien caballeros, a teñir estas señoriales ropas en juegos naranja y blanco, y azul y blanco para la fiesta (tomado de Ignacio Bejarano citado en Lewis Hanke, 1949, p. 181).

Esta mascarada organizada por los encomenderos de la Nueva España coincide con la fantasía caballeresca del proyecto de Oviedo, casi como si fuera su propio déjà vu. Pero nada tuvieron que ver entre sí salvo un trasfondo cultural y ficcional común en el pensamiento de la época. Las disputas acerca del tema de la encomienda en 1540 -que 
también se ven reflejadas en el proyecto de Oviedo- tienen un trasfondo histórico y político. Para Lewis Hanke

Los partidarios del feudalismo favorecían el sistema de la encomienda porque mantenía organizada a la sociedad como en el Viejo Mundo. Había una clase combatiente, una clase religiosa y, bajo ellas, la masa de los trabajadores. (...) [Pero el temor de la Corona era que] el Nuevo Mundo se convirtiera en un conjunto de principados feudales mal organizados y no en un imperio al mando del rey de España. (1949, p. 183)

24 La lucha entre las formas feudales medievales, por un lado, y las imperiales que procuraban reunir a los reinos bajo su mando, por el otro, guiaba los procesos históricos, las proyecciones utópicas y las disposiciones legales. La propuesta de Oviedo, utópica o reformista, entre la Edad Media y la Modernidad, quiere conciliar las dos posturas: designa al emperador como garante final y favorecedor de los caballeros encomenderos $y$, por otro lado, otorga gran poder a algunos nobles que, en Junta democrática, decidirían sobre sus "feudos" de indios. El Veedor del Oro de aquellas épocas y el cronista de la Historia General buscaron el sometimiento de los vasallos de las Indias y la libertad de decisión de los Señores nobles investidos de caballería española.

\section{El fracaso narrado en tercera persona}

Finalmente, en relación con el proyecto de 1519, nos queda explicar por qué Oviedo se refiere a sí mismo en tercera persona como personaje actuando en la corte de Carlos V. El uso de esta persona en los epígrafes a los capítulos ("dice el cronista", por ejemplo) es común en el género historiográfico, como si estuviese escribiendo un secretario o escribano. Julio César, por ejemplo, en De Bello Gallico, utiliza esta forma gramatical como modo de apología personal. La Historia, sobre todo la que tiene como modelo la de los romanos, tiende a inmovilizar los hechos y a sus héroes en monumentos cristalizados (Foucault, 1992). Así, Julio César distancia del enunciador al personaje de sí mismo para mostrarlo como "deslumbrante" y, por lo tanto, "petrificado" y "petrificador". El uso de la tercera persona tiende a conformar una figura enunciadora indiscutible, que busca suscitar una apología. Oviedo también participa de estos recursos de distanciamiento, magnificación y apología. Utiliza esta modalidad para presentarse a sí mismo como personaje en la corte del rey en competencia con Las Casas por un proyecto de gobernación. Sin embargo, su uso contiene otras particularidades, pues está combinado con la primera persona. Cito algunos de los enunciados ya evocados: "vi que tres hombres que en estas partes querían servir a Sus Majestades en estos cargos de capitanes, pidieron tres gobernaciones. El uno demandó a Sancta Marta (...)", "pero acuérdome que, preguntando al que esto pedía la causa por qué demandaba estos hábitos, dijo que porque le parescía único remedio e manera mejor (...)”. Algunas páginas después, el cronista aclara:

En el capítulo primero se dijo que el año de mill e quinientos e diez y nueve se pidieron al Emperador en Barcelona tres gobernadores, y que el que pidió la de Sancta Marta (...) dice el cronista que aquéste era él (...) (L 26, c 3 [PT III, p. 66])

Hay una duplicación o triplicación -bastante extraña- en la que el yo enunciador se inscribe en una tercera persona magnificada - "el cronista"- que reconoce haber sido otra tercera persona-personaje. Para Kathleen Myers (2007), el haberse Oviedo referido a sí mismo en tercera persona, sumado al silenciamiento de los nombres de los tres que pidieron ser gobernadores, se vincula con el tratamiento objetivo: 
[Oviedo] manipulates the use of narrative voice through omission and the use of third-person pronouns to appear more objective. The author identifies himself as the wise candidate two chapters later, when he explains that the king offered him governorship of Santa Marta again in 1524, and the governorship of the neighboring province of Cartagena the following year. (Myers, 2007, p. 47)

Si bien es probable que Oviedo quiera demostrar objetividad en el tratamiento de los hechos, no vemos claramente aquí que esto se relacione con el uso de la tercera persona cuando pocas páginas después se confiesa y continúa relatando su papel en la corte de 1524 en primera persona; o, más complicado aún, en impersonal ("se dijo") y llamándose a sí mismo "cronista" en tercera persona ("dice el cronista"), al tiempo que admite ser otro personaje al que se refiere en tercera persona ("dice el cronista que aquéste era él")18

Creemos que la distancia que entabla el enunciador Oviedo con el personaje -de sí mismo - que presenta el proyecto de caballeros de Santiago se debe al rotundo fracaso que le significó al autor el rechazo por parte de la Corona. Admite: "negándole esta Orden militar e hábitos al que lo pidió [a él mismo], no quiso entender más en ello", menosprecio que es sentido aún más en contraste con el triunfo del fraile Las Casas: "El tercero salió con la merced que pidió". El proyecto de caballeros de Oviedo quedó totalmente despreciado por la Corona y las Historias de la época ${ }^{19}$. Oviedo mismo le dedica muy pocos párrafos a lo que podría haber sido una extensa descripción de su comunidad ideal poco comprendida en la época. El cronista quiere alejar de sí mismo a aquel "personaje" que fracasó y que, además, propuso a la corona una sociedad que nada tuvo luego que ver con la política implementada por el Imperio. Por otra parte, en estos años, la figura del caballero andante y sus aventuras por tierras misteriosas se hallaban en franco proceso de desprestigio llevado adelante por el humanismo de la época. Unas páginas después del episodio "vergonzoso", admite que él mismo había sido el que había pedido los hábitos de Santiago. Aquí, al contrario, se sirve de la primera persona para subrayar con orgullo cómo sucesivamente rechaza las gobernaciones de Santa Marta y Cartagena que tan esperanzado y confiado le ofrece el rey en 1524.

29 A pesar de las propuestas reformistas que tienen gran peso a lo largo del siglo XVI, América será posteriormente -en el XVII y parte del XVIII- una gran colonia sumamente dependiente de la metrópoli española y no un conjunto de reinos-comunidades. Oviedo, al menos por un tiempo, imaginó que en las Indias los hidalgos medios serían ascendidos y decidirían -en consulta con el rey- los destinos de las Indias. Durante estos años, prefería que, en las Indias, se implementase la vieja tradición castellana del "patrimonialismo", similar a la idea de federación de la Corona de Aragón: "Carlos V tendía a considerar a cada uno de sus numerosos y extensos territorios como una entidad independiente, gobernada según sus propias leyes" (Elliot, 1969, p. 176). Pero, con América, el poder que emanaba principalmente de Castilla anhelaba una política de Monarquía Universal por la que el continente quedara sujeto a la decisión unánime de la metrópoli ${ }^{20} \mathrm{y}$ a este deseo responden los primeros proyectos de Oviedo para las Indias. El "temor" a que encomenderos y conquistadores pudieran con el tiempo hacerse muy "poderosos" en las Indias - como explica nuestro autor- desencadenó años más tarde la necesidad de instalar un sistema diferenciado de virreyes. No se permitió que este cargo fuera hereditario, como antes se había hecho con el cargo de virrey otorgado a Cristóbal Colón y heredado por Diego Colón. Los virreyes, como vicarios personales del rey de España, estarían así más fuertemente comprometidos con el poder del rey y con sus instrucciones sin mediaciones. J. H. Elliot comprende que: 
Mientras que el virrey era en la corona de Aragón el alter ego del rey, dotado de poderes administrativos y judiciales, sus equivalentes en Nueva España o Perú eran ante todo gobernadores, que gozaban de una enorme influencia dada la distancia que los separaba de la metrópoli, pero por la misma razón, se veían prudentemente privados de ciertos poderes que hubieran podido ejercer en la patria (...) la política de la corona en el Nuevo Mundo tendía a que cada uno de los organismos responsables pudiese poner freno al otro. (1969, p. 185)

El primer virrey de importancia para las Indias es Antonio de Mendoza, Camarero Real en 1530 e hijo de Iñigo López de Mendoza, virrey de Granada. Fue nombrado en el cargo en 1535 para gobernar la Nueva España con muy amplias atribuciones. Tuvo disputas legales con Hernán Cortés, el conquistador de México, a quien le fue luego otorgado tan solo el título de Marqués del Valle de Oaxaca, un pequeño territorio en comparación con la grandeza y riqueza de toda la Nueva España. Cortés finalmente acató la autoridad de Mendoza y, para reclamar ante el rey, viajó a España. Pero falleció en Sevilla unos años más tarde y fue muy poco escuchado por el monarca.

\section{Alabanza de la desaparecida ciudad de Santa María del Darién y de su gobernador y pacificador}

31 Luego de 1519, Oviedo ya no presentará a la Corte ningún pedido expreso de caballeros para la Conquista. Ya no se identificará personalmente con los soldados que van a hacerle la guerra al infiel ni con su antigua función de Veedor del Oro en las expediciones de exploración. Seguirá sugiriendo, sin embargo, que los enviados a las Indias sean idealmente de un linaje elevado y con características caballerescas, pero por otros medios. En el año de 1532, es nombrado Cronista Oficial de las Indias y se sirve de su Historia General para retomar sus convicciones. En ella, por ejemplo, el modelo ya no de capitán sino de gobernador justo y conservador de la paz es encarnado por él mismo en su relato de los hechos del año 1522 en que fue designado para gobernar la ciudad de Santa María del Antigua del Darién. El interés de este episodio, entre varios otros, está en que pone a funcionar el postulado del saber fundado en el testimonio personal para garantizar la verdad de los hechos históricos.

Vasco Núñez de Balboa fue quien realmente fundó la ciudad en 1510 en la región del Darién, al oeste del golfo de Urabá -actualmente Colombia en la zona lindera con Panamá -, donde la tierra era más fértil y los indios "menos belicosos" que los que habitaban en las cercanías de la ciudad de San Sebastián. La primera descripción de Oviedo de la región aparece en el Sumario de la natural historia. Sirviéndose de la retórica del panegírico de ciudades, Oviedo describe, en 1525 ó 1526, la ciudad de Santa María en donde erigió su casa:

Entre las casas que había en Santa María del Antigua del Darién, yo hice una que me costó más de mil y quinientos castellanos, y tal, que a un gran señor pudiera acoger en ella y muy bien aposentarle, y que quedara muy bien en que vivir, con muchos aposentos altos y bajos, y con un huerto de muchos naranjos dulces y agros, y cidros y limones, de lo cual todo ya hay mucha cantidad en los asientos de los cristianos, y por la una parte del dicho huerto un hermoso río y el sitio muy gracioso y sano, y de lindos aires y vista sobre aquella ribera. (Sumario, 1995, p. 51)

Este pequeño panegírico de la ciudad, género habitual en las narraciones de la época, tiene su tradición en los laudes Romae y en la posterior laus Spaniae de San Isidoro de Sevilla de su Crónica Universal. En esta tradición, hay un equilibrio entre el elogio de la 
fértil llanura en donde son asentadas las ciudades, la riqueza de sus edificaciones y los logros artísticos e históricos de sus habitantes. Sin embargo, Oviedo no puede desplegar todos estos tópicos para describir a Santa María, por la juventud de la ciudad que sobrevivió tan sólo catorce años. Alaba simplemente la fertilidad del terreno -río, aires y frutos- propicia para el asentamiento de cristianos, la edificación -representada mayor y principalmente por su casa "digna de hidalgos"- y, por último, su propia actuación como gobernador. E. R. Curtius (1955, p. 228-9) afirma que el panegírico de ciudades aparece en el cruce de varios géneros con la epopeya, que esencialmente es el género narrativo de las acciones trascendentales o dignas de memoria en torno a la figura de un héroe virtuoso. Por esto, la pequeña descripción de Santa María del Darién, aparecida en el Sumario, es introducción del Libro 29 de la Segunda Parte de la Historia, que consiste en una lista de méritos y padecimientos sufridos por el gobernador Oviedo, identificado hasta las últimas consecuencias con esta ciudad que lo elige como gobernador ${ }^{21}$.

En 1513, Pedrarias Dávila había asumido la gobernación de la ciudad de Santa María, fundada tres años antes por el adelantado Vasco Núñez de Balboa. Ante las hostilidades recurrentes de las comunidades indígenas resentidas contra el gobernador y sus hombres, y a causa del descubrimiento del Océano Pacífico a fines de 1513, Pedrarias decide buscar otras opciones y puntos estratégicos. Para esto funda, en 1519, la ciudad de Panamá en la costa del Mar del Sur. Éste es el primer golpe que sufre la ciudad de Santa María del Darién, pues, a causa de esto, es paulatinamente desabastecida de sus reservas de ganado, bastimentos militares y pobladores, que se trasladan a Panamá incitados por Pedrarias. Oviedo cuenta estas adversidades en el Libro 29:

E así como otros desamparaban [aquella ciudad], comencé yo a labrar, e dejé la traza e dineros a mi mujer para que hiciese mi casa; e hízola tal, que ninguna hasta aquel tiempo había en la Tierra Firme como ella. Con esto, la cibdad tenía alguna esperanza, porque aunque los otros oficiales del Rey la habían desamparado, yo no lo había hecho. E la ciudad me dio su poder para que hiciese sus negocios con el gobernador. (L 29, c 14 [PT III, p. 264])

Oviedo, como vecino, asume la resistencia que necesita la ciudad. El comienzo de esta epopeya, si se me permite la hipérbole, está marcado discursivamente por el énfasis que imprime la aparición del pronombre en primera persona singular - "comencé yo a labrar", "mi casa", "yo no lo había hecho", "e la ciudad me dio su poder". Reúne al personaje del pasado reciente y al narrador que fija, para la Historia, los méritos de su conducta y así representa discursivamente su propio heroísmo.

Es cierto lo que señala Stephanie Merrim acerca de que el libro 29 es significativamente central en la Segunda Parte de la Historia de Oviedo. En medio del caos de la mayoría de las conquistas de aquellos años que el mismo Oviedo describe, su propia gobernación será presentada como el "único alivio al caos administrativo" (Merrim, 1984, p. 113). Estos capítulos del Libro 29, junto con los del 26 y 27, son los que forman parte de lo que Kathleen Myers (2007, cap. 3) denomina la relación de Oviedo. Sus cualidades los clasifican dentro de las relaciones de prueba de méritos y de corte legal. Esta autora los compara con la Historia verdadera de la conquista de la Nueva España de Bernal Díaz del Castillo, puesto que ambos cronistas buscan demostrar su superioridad moral y autoafirmarse mediante imágenes que los alejan del caos y la desintegración. La ejemplaridad tiene una tradición importante en la cronística latino-medieval, reaparece en San Isidoro y en el modelo historiográfico alfonsí. Leonardo Funes (2008) ha destacado, en este universo cronístico, ciertos elementos que la constituyen. Los personajes históricos importantes, por ejemplo, suelen estar configurados "como adversarios de otro 
personaje que pertenece a un nivel superior" (Funes, 2008, p. 36). Efectivamente, el protagonismo de Oviedo está representado en espejo y por oposición con su gran enemigo Pedrarias Dávila, gobernador de Castilla del Oro: "Fueron pocos los que osaron mostrarse por mis amigos, porque vían notoriamente que el gobernador me era contrario e que hablaba mal en mí." (L 29, c 15 [PT III, p. 266]) Siendo superior a Oviedo y a pesar de haberlo nombrado como teniente gobernador de Santa María, Pedrarias le es contrario, lo deja en soledad y hasta desautoriza sus decisiones deshaciéndolas con órdenes contrarias. Esto magnifica discursivamente el estoicismo y la fortaleza de Oviedo: "Hice muchas ordenanzas y estatutos para pro e utilidad de la república" (L 29, c 15 [PT III, p. 266]). Resiste "por el bien de la república" a pesar de los muchos embates que le presenta su corrupto gobernador Mayor.

La ciudad de Panamá se constituye como ciudad adversaria de Santa María. Junto a esta condición particular, la figura de la ejemplaridad reúne series de polos opuestos: Santa María del Darién-Panamá, Fernández de Oviedo-Pedrarias Dávila: “[el gobernador Pedrarias les prometía a los vecinos] de los hacer ricos con que dejasen al Darién e se avecindasen en Panamá, e así se nos iba la gente e quedábamos pocos para sostener aquella cibdad" (L 26, c 4 [PT III, p. 68]). El polo de atracción de los vecinos que favorece a Santa María o a Panamá, como siempre, es el oro, que se toma de las minas o de los rescates con los indios. Fija en la escritura historiográfica, la fama y la ejemplaridad del personaje principal ante los demás. Por otra parte, si en el corpus de Cristóbal Colón, el oro hacía avanzar el viaje y el relato; en Oviedo, la posibilidad del oro detiene el nomadismo de los españoles y es inicio de una colonia. El oro atrae a los pobladores tentados por el sedentarismo que una villa o ciudad cercana a una fuente de riqueza tiene para ofrecerles:

e hice meter en aquella ciudad el oro que he dicho, a causa de lo cual, los vecinos que estaban alterados e para se ir a Panamá, se sosegaron, e aún se venían otros al Darién de aquellas islas y de otras partes. (L 26, c 4 [PT III, p. 68])

Es por esto por lo que algunos estudiosos tienen a Oviedo por uno de los primeros criollos de la colonia americana ${ }^{22}$, ya es un ciudadano de la colonia hispanoamericana. Los propósitos de Oviedo, al menos en esta instancia, son diferentes de los de algunos conquistadores y soldados que buscaban el enriquecimiento y el ascenso rápidos para retornar "premiados" a la sociedad de origen; la alternativa del Cronista Oficial, según lo describe Alberto Moreiras, está en que los españoles "perseveren en la tierra" indiana (2008, p. 31).

Lo que más nos interesa aquí es la función didáctica de la figura ejemplar -de humildad, equidad y valores cristianos-, común a las crónicas españolas. Para esto, la semblanza sirve como una de las operaciones de mayor recurrencia en la construcción del personaje como figura ejemplar. Se subraya la trascendencia moral del ejemplo de los "grandes" hombres en general. En Oviedo, su servicio "ejemplar" al Emperador y a Dios trasciende en dos posibles direcciones señaladas en la Historia: es modelo de imitación pero, injustamente, no es reconocido ni agradecido -o es envidiado- por los que fueron favorecidos con su acción. Uno de los principales servicios de este teniente gobernador a la Conquista en Tierra Firme -lo repite insistentemente - fue haber: "pacificado toda la costa, desde el Darién, la vía del Oriente, hasta el puerto de la Ramada" (L 26, c 4 [PT III, p. 68]). Su modo de pacificar a los indios "flecheros" de la costa de Tierra Firme es muy particular. En 1521, para paliar la extrema necesidad en que se vio la ciudad de Santa María, Oviedo incentiva el trueque de hachas que los indios flecheros estimaban mucho. 
Tiene gran éxito en la operación, sobre todo porque, beneficiados por las buenas relaciones, los indios de la región no vuelven a atacar a los españoles. Cuando al protagonista se le terminan las pesadas hachas vizcaínas, se las ingenia para hacer unas hachuelas con los aros de hierro viejo de los toneles: "que no valían nada, así por ser sin acero como por ser mal templadas" (L 26, c 4 [PT III, p. 69]). Los indios las aprecian mucho por ser muy livianas y poder manejarlas con una sola mano. Cuando éstas se le acaban, tiene la idea de conseguir una muela grande de barbero para afilar las hachas viejas de los indios. Envía de esta manera unas carabelas para hacer trueque con los indios pero oculta los molejones: "debajo de cubierta afilaban [las hachas] e concertaban, e se les tornaban a los indios, e no les costaba menos que cuando las compraron" (L 26, c 4 [PT III, p. 69]). El ardid engañoso de Oviedo consiste en permitir que los indios adquieran hachas para cortar sus árboles, pero ocultarles la herramienta de afilar y volver a vendérselas por el mismo precio. Por último, una astucia coloca al protagonista en el lugar de verdadero personaje "ejemplar" de su relación: pacifica a los indios flecheros trocando las hachas recicladas y de poco valor por arcos y flechas, de modo que quedan los indios "desarmados" y, así, resulta más fácil someterlos o "pacificarlos" para que los españoles se apoderen del oro que esconden.

Hay una gradatio en el relato que acumula progresivamente pruebas de astucia y enriquecimiento rápido del entonces Veedor del Oro. El periplo culmina en un autorreconocimiento destacable: "pienso yo que fue servido Dios de mi diligencia" (L 26, c 4 [PT III, p. 70]). Antes menciona, incluso, que gracias a él también ha sido servido el Emperador. Oviedo actúa con el trueque como esos "mercaderes astutos" que piden por su mercadería mucho más dinero de lo que vale ${ }^{23}$. Valora la astucia y la ambición porque las vincula con las sociedades complejas en contraste con las ingenuas y simples de los indios. Si bien el autor no menciona explícitamente el valor de trascendencia que podría tener su modelo de adelantado y gobernador, admite que provoca la envidia de sus contemporáneos: "pesando a los envidiosos del bien que Dios hacía a aquella ciudad del Darién con aquellos rescates, se barajó e alteró maliciosamente esta granjería; pero Dios tuvo cuenta con todos" (L 26, c 4 [PT III, p. 69]). Enfatiza cómo la Divina Providencia lo favorece al tiempo que condena a sus enemigos. Esta relación de Oviedo tiene las particularidades de los discursos mitificadores del protagonista propios de cierta rama de la tradición que Beatriz Pastor (2008) llamó "discurso narrativo del fracaso". Tal como sucede en este conjunto de textos, el propósito inicial, la sobrevivencia de la ciudad del Darién en este caso, no prospera. La ciudad desaparece del mapa. Pero su Historia es un relato optimista de triunfos y virtudes personales. Por otro lado, consiste en una enumeración de los padecimientos sufridos por el teniente gobernador: la escasez de todo, el abandono y el ninguneo moral frente al mérito y al servicio que debía merecer recompensa. Esto explica por qué su ejemplaridad va seguida de la envidia e ingratitud de los otros: es otro escollo más en el camino del "humilde" gobernador audaz y pacificador en su lucha por la persistencia de su ciudad.

\section{Orden y castigo: instrucciones para gobernara los españoles en las Indias}

41 Además de la pacificación ideal de los indios flecheros, todo el episodio le sirve a Oviedo para autorrepresentarse como gobernador ejemplar de los vecinos españoles en las Indias. Dos son las imágenes más llamativas con las que se presenta como gobernador 
ante los ojos del lector enfatizando en la constancia con la que castigaría a los pecadores y el temor que en ellos generaba: "como luego me puse con la vara de justicia en castigar los pecados públicos, presto fui aborrecido (...) en cada cosa de las que prohibí, fui constante en castigar los transgresores" (L 29, c 15 [PT III, p. 265]). La segunda imagen también hace hincapié en el temor generado y en la constancia: "fui temido juez, por no haber disimulado los pecados públicos, ni dejado de hacer justicia (aunque templada fuese); e cada uno sabía que no tenía nada en mí para se quedar sin pena o moderada corrección, si culpado fuese" (L 29, c 15 [PT III, p. 266]). Enumera una larga cantidad de castigos a las transgresiones a reglas civiles y morales de los ciudadanos: no consiente que se coma carne los sábados ni que se tengan mancebas públicas, hace quemar todos los naipes del pueblo en la plaza central, castiga las blasfemias, condena los robos aunque provengan de funcionarios, prohíbe que se cargue a las indias como si fueran asnos, manda a azotar y sacarle algunos dientes a una mujer porque, sin pruebas, había acusado a su marido de querer asesinarla, lo que posteriormente trajo serios problemas a Oviedo en España, pues la mujer le levantó cargos que llegaron a ser tratados por el Consejo Real de Indias. Por último, pide a este Consejo que se le corte la mano derecha y el pie izquierdo -además de hacerle perder la mitad de sus bienes- a Simón Bernal, un "traidor" que intentó asesinarlo varias veces.

Los crueles castigos que desata Oviedo sobre sus vecinos "pecadores" no deben entenderse como actos de irracionalidad y salvajismo poco piadosos sino como todo lo contrario: se trata de una burocracia del castigo que encarna Oviedo para "corregir" a los transgresores. La penalidad que Oviedo ordena que se le haga a la mujer se clasifica dentro de los parámetros de los suplicios y tormentos comunes del sistema penal y judicial previo a los siglos XVIII y XIX, muy bien estudiados por Michel Foucault (2002). De acuerdo con este autor, consideramos que el rigor sobre los cuerpos de los condenados era tenido como punto de confluencia entre el juicio de los hombres y el de Dios: "el suplicio es una anticipación de las penas del más allá; muestra lo que son, es el teatro del infierno; los gritos del condenado, su rebelión, sus blasfemias, significan ya su irremediable destino." (Foucault, 2002, p. 51). Con este criterio, por servir al Emperador y a Dios, Oviedo condena a la mujer y a Simón Bernal a aquellos tormentos físicos. Pero, como también admite Foucault, los suplicios no eran las penas más frecuentes. Sólo eran el castigo apropiado para delitos serios y por esto Oviedo fue juzgado por excesivo y multado con el pago de veinte pesos de oro por haber sido muy duro en el castigo que impuso a la mujer que había testimoniado falsamente acerca de su esposo. Hay algo del exceso en la ejecución de las penas y los suplicios que quizás pueda ser explicado por la ritual evocación del poder que implica todo acto de castigo: "debe existir, en la liturgia de la pena, una afirmación enfática del poder y de su superioridad intrínseca” (Foucault, 2002, p. 54).

43 A nuestro entender, los castigos infligidos confirman el poder de Dios y del imperio en las Indias. Oviedo como gobernador precisa $-\mathrm{o}$ al menos así se representa en su texto- ser enfático al castigar, para así reafirmar el poder imperial de la metrópoli cuyo centro se encuentra muy lejos en España. Como autor, exhibe reiteradamente los castigos que ejecutó, como pruebas de su rectitud y lealtad al poder castellano. El haber quemado todos los naipes en la plaza pública para castigo de los jugadores y viciosos podía ser considerado una pena más corriente. Ahora bien, el escarmiento debía ser expuesto y visto por todos para atemorizar y servir de lección. Se trata del castigo ejemplar, práctica común entre los conquistadores y, también, al parecer, entre los indios ${ }^{24}$. Con esto, el 
gobernador hace ostentación pública también de su propio poder. Lo mismo sucede, por ejemplo, al narrar la cesión de su cargo:

Yo no quería aceptar el cargo así porque me tenía por más honrado con ser oficial del Rey, que no con ser teniente suyo [de Pedrarias] (...) Finalmente rogándomelo él e otros, acordándome que aquella cibdad se despoblaría, e yo perdería mi hacienda, si no había quien se doliese, acepté el cargo, y el gobernador me lo mandó de parte de sus Majestades. (L 29, c 14 [PT III, p. 264-265])

Hay un énfasis puesto en demostrar cómo el poder es ejercido apropiadamente por Oviedo desde todo punto de vista. Su legitimación proviene de todos lados: de Pedrarias y sus allegados, de los vecinos, de la ciudad misma, de su propia hacienda que quedaría vacía y, finalmente, “de parte de sus Majestades". Se cumple con esto el necesario pacto político de traslado de la autoridad del pueblo al soberano según la visión republicana del poder político. Así, al tiempo que el personaje de Oviedo exhibe, con el castigo ejemplar, su autoridad entre los vecinos, el enunciador recopila todos los testimonios que demuestran públicamente la legitimidad de su posesión del cargo de teniente gobernador. El uso de la amplificatio aquí tiene la función de magnificar la actitud virtuosa del personaje para dirigir a los lectores hacia una determinada distinción entre los buenos actores de la Conquista (Oviedo) y los malos (Pedrarias).

Ahora bien, a pesar de que se haya hecho rogar tan insistentemente por todos para asumir el cargo, Pedrarias no reconoce su autoridad en varias ocasiones: "Al que yo castigaba [admite Oviedo], si apelaba, le absolvía el gobernador e le daba dineros" (L 29, c 15 [PT III, p. 266]). Incluso, Pedrarias intentó suspender el castigo a Simón Bernal. Por último, mientras Oviedo se encuentra en España en 1523, este Gobernador Mayor, "enojado del poder que la cibdad del Darién me había dado, fue allá e de hecho la despobló (...) por el odio que le tenía porque la había poblado el adelantado Vasco Núñez, como por acabar de destruirme." (L 29, c 20 [PT III, p. 285-286]). En este punto, nos preguntamos cómo puede entenderse que Pedrarias le "ruegue" al entonces Veedor del Oro que se asuma como gobernador de la ciudad del Darién y luego este mismo la despueble y lo desacredite. Pérez de Tudela $(1959$, p. 85) explica este rencor posterior del gobernador Mayor a partir de que, por las manos de Oviedo, pasaran los papeles del proceso contra Pedrarias y sus hombres sobre la irregular causa del asesinato de Vasco Núñez de Balboa. Pero nuestro cronista no registra esto como origen de su enemistad con el gobernador Mayor. La contradicción manifiesta queda sin respuestas en la Historia General.

Tampoco se entiende que Oviedo tenga a tantos vecinos en su contra y que éstos al mismo tiempo también le hayan rogado en más de una ocasión que asuma la gobernación de Santa María. En tres ocasiones comprobadas intentan asesinarlo en la ciudad del Darién: la primera, en un motín organizado por el bachiller Corral; la segunda, Simón Bernal, resentido por una de las penas excesivas que Oviedo le impuso a su padre, le da una cuchillada en la cabeza descendiendo hasta la quijada y dos cuchilladas más en el hombro izquierdo. Los párrafos de Oviedo dedicados al relato de su propio asesinato frustrado como casi todos los pasajes autobiográficos de la Historia General- son de una precisión narrativa que sobresale del conjunto de relatos del texto. Reproducimos algunos:

Y en este instante llegó por detrás el Simón Bernal con un puñal luengo muy afilado (aunque traía otra espada ceñida), e dióme una gran cuchillada en la cabeza, e descendió cortando por debajo de la oreja siniestra, e cortóme un pedazo grande de la punta e hueso de la quijada, y entró hasta media mejilla; e fue tan grande e honda la herida, que me 
derribó e dio conmigo en tierra; e al caer, dióme otras dos cuchilladas sobre el hombro izquierdo (...) Estando de esta manera herido, me llevaron a mi casa, e pedí a mucha priesa un confesor, porque conoscí bien el peligro en que estaba; e venido un barbero cirujano, como me vido, no me quería curar, e dijo que para qué había de curar a un hombre muerto. E con importunación de los que ende allí estaban, me curó, sin esperanza de todos los que me vieron, que pudiese vivir tres horas. (...) E de allí en adelante entendí en mi salud, la cual, al parecer de los hombres, me dio Dios de poder absoluto, porque ninguno de cuantos me vieron herido, pensó que podía vivir ni salir de aquel día; mas paresce ser que me tenía Dios guardado para otros trabajos. (L 29, c 18 [PT III, p. 277]). ${ }^{25}$

El tercer intento de homicidio consistió en una conspiración entre varios, que falló al intentar matarlo con una ballesta cuando salió desnudo a refrescarse a su balcón. A pesar de todo esto, Oviedo no deja de insistir en que los ciudadanos: "me tenían por padre, e yo había sustentado aquella república, que no la quisiese desamparar" (L 29, c 16 [PT III, p. 274]). Si, por un lado, los ruegos de unos y de otros legitiman legal y discursivamente la gobernación de Oviedo en la ciudad del Darién, el relato de las contrariedades que Pedrarias y sus enemigos le "presentan" al protagonista está también dirigido por la tradición hagiográfica de la Vida de Santos y Mártires.

Ahora bien, de la elección de estas retóricas y del uso del castigo ejemplar se desprende una visión de gobernación ideal cuyos principios esenciales son la disciplina, la represión y el control. Son imágenes utópicas del orden (Davis, 1985) que se imponen sobre el caos y la corrupción hipotéticamente anteriores a la asunción de gobierno. Estas imágenes se proyectan a futuro mediante el recurso persuasivo del modelo: "cuando se trata de una conducta o un comportamiento particular, el modelo puede servir para incitar a una acción inspirada en él" (Perelman, 1995, p. 5726). El narrador construye el prestigio de su personaje y el suyo propio a través del principio insobornable y constante del hacer justicia. La representación de Oviedo persigue el fin de ser imitada y tiene intenciones normativas sobre el proceso de conquista y colonización. Busca reprimir las "transgresiones" vinculadas a los instintos de la lujuria, el vicio, el abuso y la mentira mediante la aplicación de "leyes justas" ("la vara de la justicia"). El castigo representa tanto la ley imparcial del soberano - puesto que el criminal es por definición un enemigo del príncipe- como una réplica directa de parte del ofendido (Foucault, 2002, p. 53). El lector se identifica con la víctima y proyecta sobre él sus deseos vengativos constantes contra los "injustos". La escritura "modélica" de Oviedo se sirve de estas instancias y activa la catarsis en el lector. Emerge, así, un modelo de gobernador prestigioso y deseado para las Indias.

\section{Ordenar la ciudad ideal: visible/invisible, dentro/fuera, público/privado, españoles/indios}

Oviedo tiene que hacer frente a una rebelión india muy particular para conservar la paz interior de la ciudad. El cacique de Bea, que "vivía en las lagunas" cerca del Río Grande, mostró sus verdaderas intenciones cuando el capitán Martín de Murga y sus hombres fueron "traidora" y humillantemente muertos por los indios de esta región: "le llevaron rastrando con mucho placer e risa, cantado su areito e lo dejaron para que las aves se lo comiesen." (L 29, c 15 [PT III, p. 268]). A raíz de esta "deslealtad", Oviedo decide enviar una armada contra Bea y otros indios: 
Se sospechaba que otro cacique, llamado Guaturo, se había confederado con el de Bea e con otro que era notorio enemigo de los cristianos (e muy varón), que se llamaba Corobari, e alzado andaba días había, e tenía dentro en la cibdad, en casa del bachiller Corral (al cual estaba encomendado por repartimiento) la madre e la mujer e los hijos, e era cercano pariente de una india que el bachiller tenía por manceba, en la cual tenía hijos; y deste Corobari, como de ladrón de casa, teníamos gran recelo, porque estaban dentro en el pueblo parte de sus indios, e cada día le podían avisar de la poca gente e vecindad que ya éramos; con todas estas sospechas e indicios, que cada cosa dellas eran de temer, hice armar e poner a punto tres canoas e una barca. (L 29, c 15 [PT III, p. 268])

51 Estos párrafos de la Historia General son los que pertenecen al género de la relación y se distancian de la narración historiográfica en su versión más pura. Por tener "en su casa” y "dentro de la ciudad" a indios de Corobari, es que el bachiller Diego de Corral, supone Oviedo, busca impedir el envío de gente armada contra los caciques. Se da un importante debate público entre Corral y Oviedo, en el que éste llama "perro" a Corobari por estar matando de a poco a los indios cristianos y sirvientes de la ciudad. También acusa al bachiller de tener nativos "ladrones" en su propia casa. Corral consigue organizar un motín e impide el envío de la armada. Pero Oviedo, "abusando de su poder" (Pérez de Tudela, 1959, p. 86), lo denuncia a la justicia eclesiástica y seglar y lo envía preso en un navío a Castilla "donde tenía su mujer, sin la cual estaba once o doce años había, e público amancebado, e que con la información de sus excesos, se fuese, por hombre perjudicial e no conveniente a la república" (L 29, c 16 [PT III, p. 272]). Finalmente, Oviedo toma preso al cacique Corobari, obtiene de él la confesión de que era enemigo de los cristianos y, con consejo del licenciado Salaya que traía poderes del obispo Peraza, manda Oviedo quemar al cacique, aunque ahogándolo primero.

Luego, el teniente gobernador de Santa María comienza a perseguir al cacique Guaturo:

En este tiempo, tomé yo ciertas espías del cacique de Guaturo que servía a un vecino del Darién, el cual se había alzado e había acordado de se juntar con el cacique de Bea, para matar a todos los que estábamos en el Darién, e pegar fuego a aquella cibdad. E como yo sentí la cosa, viendo el peligro notorio en que la cibdad estaba, acordé de ir en persona a buscar al cacique. (L 29, c 16 [PT III, p. 273])

Se hace cada vez más evidente la escena de miedo y deseo de sometimiento del Otro, tal como la define Homi Bhabha (2002) para los textos coloniales ${ }^{27}$. La fantasía socava el realismo de la narración, que se delata cada vez más en su subjetividad. Cuando llega a la región de Guaturo, Oviedo "halla alzado al cacique" (aunque, en realidad, lo encuentra escondido en el arcabuco), pero, sin mayores inconvenientes, lo prende junto con toda su familia y apresa también a su capitán principal, el indio Gonzalo:

E confesó [Guaturo] que iba a juntarse con el cacique de Bea para venir con él a dar una noche sobre nosotros, e pegar fuego a la cibdad e matar los cristianos. Mandé que los indios que se tomaron alzados fuesen repartidos por los compañeros que conmigo fueron, e lo mismo hice con los de Corobari (...) Y en el camino, se hizo una horca más alta que una lanza de armas, e allí fue ahorcado el capitán Gonzalo, para que los indios de Bea lo pudiesen ver desde las lagunas (...). Ido al Darién, quedó ahorcado en la plaza el cacique de Guaturo; con lo cual e con la justicia que se había hecho pocos días antes del cacique Corobari, quedó aquella ciudad e provincia muy segura. (L 29, c 16 [PT III, p. 273])

Son interesantes los variados modos de "pacificación" que se exponen. El cacique de Bea, por ejemplo, tan sólo es amedrentado, a pesar de que sobre él debieron haber caído los deseos de venganza por la muerte de Martín de Murga. En cambio, en su lugar, con 
muerte aparentemente injusta y excesiva, fueron asesinados los caciques Corobari y Guaturo.

Podríamos explicar el sinsentido de los hechos con algunas respuestas provenientes del mismo texto y otras de la situación histórica de enunciación. Bea había matado a traición a su encomendero Martín de Murga. En su razonamiento, Oviedo concluye que el mejor y más aleccionador castigo que puede infligir sobre el traidor es asesinar cruel y espectacularmente a sus confederados. Por esto, es preparada una hoguera para Corobari: "porque los indios temen mucho el fuego", y la horca bien alta para el capitán indio Gonzalo: "para que los indios de Bea lo pudiesen ver desde las lagunas". Pérez de Tudela (1959, p. 87) da a entender que Oviedo, quien no se caracteriza por su amor al riesgo, no se habría animado a enfrentar directamente a Bea, de mayor poder bélico. Estas conjeturas quizás expliquen por qué el teniente gobernador decide ir contra Corobari y contra Guaturo y no contra quien fue el origen de los enfrentamientos. Sin embargo, el asesinato de Martín de Murga y de sus hombres tampoco resulta razón única y convincente para desplegar toda esta cruzada. Sobre todo, porque, en un capítulo bastante posterior -y quizás escrito también muchos años después-, destinado a hacer un catálogo de los capitanes "codiciosos" o de mal comportamiento que tuvieron fines desastrados, Oviedo no parece muy partidario de Martín de Murga y se halla, en cambio, más bien favorecedor del cacique de Bea: "El capitán Martín de Murga, que en diversas partes e tiempo había muerto hartos indios (...) le mataron cenando en casa del cacique de Bea (...) porque este capitán codicioso le fatigaba porque le diese oro." (L 29, c 33 [PT III, p. 345]). De acuerdo con Pérez de Tudela, consideramos que, aunque Oviedo no lo haya admitido, existía de fondo el deseo de ampliar y asegurar las encomiendas de esclavos para que no decayese la empresa de extracción del oro, ya alarmante en el Darién: "Mandé que los indios que se tomaron alzados fuesen repartidos por los compañeros que conmigo fueron, e lo mismo hice con los de Corobari". Esto demuestra uno más de los fracasos en el intento por tener a los indios como vasallos libres de la corona española, lo que luego se repetirá en casi todas las colonias ${ }^{28}$. El teniente gobernador busca defender su ciudad hasta las últimas instancias y actuando él mismo como conquistador y "pacificador" de las regiones próximas.

Un último tema interesante que se desprende del análisis del episodio es el de las mancebas indias públicas ${ }^{29}$. Oviedo consigue echar de la ciudad y enviar a Castilla al bachiller Corral, muy querido en el Darién por los vecinos, los indios y también por Pedrarias; y al especiero Luis de Córdoba - padre de Simón Bernal- por "enemigos de la república" y por tener mancebas públicas. Corral, además, tiene un hijo mestizo, Perico, con una de ellas, la india Elvira. No es una novedad si afirmamos que, para la Historia General de Oviedo, el mestizaje es un error que desatiende la preservación de los linajes españoles y la pureza de sangre. El relato de la muerte de la mujer de Oviedo es significativo al respecto, puesto que su lamento pone en juego varios tópicos reveladores:

E otro día, enterré a mi mujer, que había diez días que estaba enferma. E con el dolor de pérdida tan triste para mí, transportado e fuera de sentido, viendo muerta a mi mujer, que yo amaba más que a mí, estuve para perder el seso; porque demás de tan dulce compañía, e ser mi deseo vivir en estado matrimonial, como cristiano, no era acostumbrado a las mancebas que mis vecinos tenían, e aún algunos duplicadas. (L 29, c 14 [PT III, p. 265])

57 También fallecen dos de sus hijos, pero el lamento sobre ellos se detalla poco en el texto, sus muertes se cuentan entre sus otros padecimientos. La construcción patética del discurso sobre la muerte de la mujer se inscribe en la tradición del género consolatorio. El 
lamento se articula sobre la locura que el fallecimiento le provoca al autor y sobre el infortunio de ser llevado por esta razón a la tentación de vivir poco cristianamente con mancebas indias. Como suele suceder en esta tradición, hay una conjunción paradójica de debilidad y fortaleza: el autor se muestra vulnerable sentimentalmente pero ejemplar y resistente en su entereza moral cristiana. En ningún momento alude a que su oficio de teniente gobernador se haya visto interrumpido por estos hechos. Son importantes los "límites" que Oviedo impone a la ciudad. Autoriza que ésta tenga siervas indígenas, pero si éstas son amancebadas, deben quedar relegadas al ámbito de lo privado. Desde que se asume como gobernador, prohíbe que esta situación se muestre públicamente.

Del mismo estatuto sospechoso de las mancebas públicas, participan los "espías" indios que están "dentro de la ciudad". Son los parientes de Corobari y de Bea que sirven a españoles. Según Oviedo, informan de la decadencia y de la pobreza en la que está entrando la ciudad del Darién. De esta manera, impide que en su ciudad se vuelvan visibles dos circunstancias. La primera: no permite, a la mirada de los españoles -incluso a la del lector español-, el amancebamiento con indias y el mestizaje en sus herederos. Sólo los vecinos españoles y las relaciones entre ellos deben ser visibles dentro de la ciudad. En segundo lugar, también censura la mirada de los indios sobre la ciudad, en tanto que prohíbe que todo "espía" dé cuenta de su ruina e inocultable pobreza. Oviedo tiene que demostrar la grandeza de su ciudad porque esto afirma su propia imagen virtuosa y las injusticias de Pedrarias. Quiere exhibir, en cambio, el poder y el crecimiento de Santa María a los lectores y a los nativos próximos al Darién. Los indios que están dentro de la ciudad son sospechados - hay "indicios"- de ser especies de "infiltrados del exterior". Con la hoguera de Corobari y con la horca del capitán de Guaturo, el teniente gobernador marca los límites de su poder y de la ciudad española clausurada a los Otros. La exhibición o espectáculo de poder militar también constituyen desde siempre a la ciudad, lo que será definitorio, por ejemplo, en la cultura del barroco. Los indios son combatidos "afuera". El texto fundador de Oviedo contiene en sí el germen de algunas de las particularidades de lo que será la cultura barroca, en donde la guerra será constructora y constitutiva de la ciudad ${ }^{30}$. Se hace sentir con mayor notoriedad la necesidad de reforzar los nexos de las fuerzas guerreras, legales e ideológicas en Indias con la ortodoxia y la autenticidad que encarna el poder imperial. Los espías indios y los españoles relacionados con ellos, es decir, los que cruzan las fronteras -y el amancebamiento público de indias y el mestizaje son claramente un cruce de este tipo-, son expulsados de la ciudad de Santa María del Darién. En esta misma dirección, Oviedo envía a Corral de vuelta a España alegando en su contra su amancebamiento público de la india Elvira; pero, también, por su política de alianzas con los nativos, iniciada ya por el adelantado Vasco Núñez de Balboa. Ambos motivos para el exilio del bachiller implican cruces que Oviedo no permitirá para su ciudad.

\section{Conclusiones}

En sus primeros años en Indias, las propuestas de Fernández de Oviedo son elevadas directamente a la Corona mientras que, en un segundo momento, ya asumido como Cronista Oficial, recurre a su relato historiográfico edificante para ofrecer modelos de conquistadores y de gobernantes, al tiempo que desaprueba algunas acciones y hechos recientes en el Nuevo Mundo. Con los primeros fracasos, abandona los proyectos y ciertos ideales de establecimiento de una casta noble y altamente hidalga en territorio 
descubierto. Mediante la utopía del control, propone reforzar la soberanía del rey y trasladar las formas culturales y de sociabilidad provenientes de la metrópoli española. Como hemos afirmado más arriba, es correcta la propuesta de pensar a Oviedo y a su discurso como modelo incipiente de la conciencia colonial y criolla, sobre todo, en la segunda parte de su escritura, que comprende la Segunda y Tercera partes de su Historia General, ampliamente corregidas en la colonia de Santo Domingo de la isla Española. Junto con éstas, también consideramos las correcciones hechas a la Primera Parte y publicadas post-mortem. Hay, en este segundo momento de escritura de Oviedo, un ideal de ciudad controlada y excluyente que es el mismo que luego guiará ideológicamente a la Patria del Criollo en los centros virreinales de Hispanoamérica. A raíz de este momento incipiente del proceso de colonización del Imperio español que le toca asumir al Cronista oficial, su obra todavía confunde los límites ideológicos con los geográficos de la ciudad o "república". A la sociedad criolla en las colonias americanas, salvo importantes excepciones, le serán suficientes las rígidas demarcaciones ideológicas en un mismo espacio geográfico. Oviedo idealiza un espacio cerrado y controlado, disciplinado y represivo, que por otra parte sigue -como lo hace el ideal de ciudad europea y como lo hará la cultura barroca - una política filoaristocrática. Si nos detenemos particularmente en su aborrecimiento del mestizaje, la ciudad utópica que propone el cronista expulsa al Otro y a todo lo que signifique un cruce con él.

\section{BIBLIOGRAPHY}

Adorno, R. (1990). La construcción cultural de la alteridad: el sujeto colonial y el discurso caballeresco. En Simposio de Filología Iberoamericana, Sevilla: Facultad de Filología.

Adorno, R. (1992). Los debates sobre la naturaleza del indio en el siglo XVI: textos y contextos, Revista de Estudios Hispánicos. Letras Coloniales, Universidad de Puerto Rico- Facultad de Humanidades, (9), 47-66.

Adorno, R. (2007). Polemics of possession in Spanish American narrative, New Haven \& London: Yale University Press.

Aquino, T. de (2000). Suma teológica. Madrid: Biblioteca de Autores cristianos.

Aristóteles (2007). Política. Madrid: Espasa-Calpe.

Bataillon, M. (1950). Erasmo y España, Estudios sobre la historia espiritual del siglo XVI., trad. de Antonio Alatorre, México: FCE.

Beckjord, S. H. (2009). Gonzalo Fernández de Oviedo y la incipiente conciencia criolla en la historiografía de Indias. En J. M. Vitulli y D. M. Solodkow (Eds.), Poéticas de lo criollo (pp.61-79). Buenos Aires: Corregidor.

Bhabha, H. K. (2002). El lugar de la cultura, Buenos Aires: Manantial.

Bolaños, A. (1988). El líder ideal en el libro de caballerías y las crónicas de indias de Gonzalo Fernández de Oviedo. Lexington: Diss., University of Kentucky. 
Bolaños, A. (1990). Panegírico y libelo del primer cronista de Indias Gonzalo Fernández de Oviedo. Thesaurus. Tomo XLV (3).

Brading, D. (1998). Orbe Indiano. México: FCE.

Casas, Bartolomé de las (1981). Historia de las Indias. (A. Millares Carlo, Ed.). México: FCE.

Castro, A. (1984). España en su historia. Barcelona: Ed. Crítica.

Covarrubias, S. de (1611). Tesoro de la lengua castellana o española. Madrid: Luis Sánchez impresor del Rey.

Curtius, E. R. (1955). Literatura europea y Edad Media latina. México: FCE.

Davis, J. C. (1985). Utopía y la sociedad ideal. México: FCE.

Domínguez Ortíz, A. (1998). Estudios americanistas, Madrid: Real Academia de la Historia.

Elliot, J. H. (1969). La España Imperial 1469-1716. Barcelona: Editorial Vicens-Vives.

Erasmo de R. (2007). Educación del príncipe cristiano. (Edición y estudio preliminar de Pedro Jiménez Guijarro, traducción de Pedro Jiménez Guijarro y Ana Martín). Clásicos del Pensamiento, Madrid: ed. Tecnos (Grupo Anaya S.A.).

Foucault, M. (1992). Genealogía del Racismo. Montevideo: Editorial Altamira/Nordan Comunidad.

Foucault, M. (2002). Vigilar y castigar. Nacimiento de la prisión. Buenos Aires: Siglo XXI.

Funes, L. (2008). Elementos para una poética del relato histórico. En A. Arizaleta (Ed.), Poétique de la chronique: L'écriture des textes historiographiques au Moyen Âge (péninsule Iberique et France) (pp. 241-273). Toulouse: Université de Toulouse-Le Mirail.

Gerbi, A. (1978). La naturaleza de las Indias. México: FCE.

Hanke, L. (1949). La lucha por la justicia en la conquista de América. Buenos Aires: Sudamericana.

Kohut, K. (2002). Teoría literaria humanística y libros de caballerías. En Carro Carbajal, Puerto Moro, Sánchez Pérez (Eds.), Libros de caballerías (de Amadís al Quijote) Poética, lectura, representación e identidad (pp.173-185). Salamanca: SEMYR.

Lafaye, J. (1997). Mesías, cruzadas, utopías, México: FCE.

Leonard, I. (1996). Los libros del conquistador, relaciones indígenas de la Conquista. México: FCE.

Martínez Peláez, S. (1998). La Patria del Criollo. México: Fondo de Cultura Económica.

Merrim, S. (1984). “Un mare magno e oculto”: Anatomy of Fernández de Oviedo's Historia General y Natural de las Indias. Revista de estudios hispánicos. (11), 101-120.

Moreiras, A. (2008). Notes on Primitive Imperial Accumulation. Ginés de Sepúlveda, Las Casas, Fernández de Oviedo. En M. Moraña y C. Jáuregui (Eds.), Revisiting the Colonial Question in Latin America (pp.15-38). Madrid: Iberoamericana.

Mumford, L. (1982). La utopía, la ciudad y la máquina. En F. Manuel (Comp.), Utopías y pensamiento utópico (pp.31-54). Madrid: Espasa Calpe.

Myers, K. (2007). Fernández de Oviedo's chronicle of America. A New History for a New World. Austin: University of Texas Press.

Oviedo, G. Fernández de (1535). La historia general de las Indias. Libros 1-20. Sevilla: imprenta de Juan Cromberger [imágenes digitalizadas por Patrimonio Nacional, Palacio Real de Madrid]. 
Oviedo, G. Fernández de (1959). Historia General y Natural de las Indias. (J. Pérez de Tudela, Ed.). Madrid: Atlas, Biblioteca de Autores Españoles. [Para todas las citas de este libro de Gonzalo Fernández de Oviedo, utilizamos esta edición].

Oviedo, G. Fernández de (1974). Las memorias de Gonzalo Fernández de Oviedo. 2 vol. (Antología de Quinquagenas de la nobleza española editada por Juan Bautista Avalle-Arce). North Carolina: Department of Romance Languages, University of North Carolina.

Oviedo, G. Fernández de (1519). Libro del muy esforçado [e] inuencible Cauallero de la Fortuna propiam ete llamado don claribalte q[ue] seg u su verdadera interpretaciõ quiere dezir don Felix o bienauenturado nueuam ete imprimido [e] venido aesta lengua castellana, el qual procede por nueuo [e] galan estilo de hablarpor medio de gonçalo Fernandez de ouiedo alias de sobrepeña], Valencia, Juan Viñao. [Biblioteca Digital Hispánica].

Oviedo, G. Fernández de (1526). Sumario de la Natural Historia. Toledo: Ramón de Petras. [Biblioteca Digital Hispánica].

Oviedo, G. Fernández de (1995). Sumario de la Natural Historia. (N. del Castillo Mathieu, Ed.), Bogotá: Universidad de Bogotá.

Pastor, B. (2008). El segundo descubrimiento. Barcelona: Edhasa.

Pavón Romero, A. (2008). La modernidad de la monarquía hispánica. En A. Velasco Gómez (Coord.), Significación política y cultural del humanismo iberoamericano en la época colonial (pp.315-337). México: UNAM y Plaza y Valdés.

Perelman, C. y Olbrechts-Tyteca, L. (1995). La inventio: las técnicas argumentativas. En A. Reale y A. Vitale (Comps. y trads.), La argumentación, una aproximación retórico-discursiva (pp.47-61). Madrid: Ars.

Pérez de Tudela, J. (1959). Estudio preliminar. En G. Fernández de Oviedo, Historia General y Natural de las Indias (pp. I - CLXXV). Madrid: Atlas, Biblioteca de Autores Españoles.

Pupo Walker, E. (1982). La vocación literaria del pensamiento histórico en América. Madrid: Gredos.

Sicroff, A (1982). El Lumen ad revelationem gentium, de Alonso de Oropesa, como precursor del erasmismo en España. En E. Bustos Tovar (coord.), Actas del cuarto Congreso Internacional de Hispanistas, (pp. 655-664). Vol. 2. Salamanca: Universidad de Salamanca .

Sicroff, A. (1977). En torno a las ideas de Américo Castro. En F. Lopez et al., Actas del quinto Congreso Internacional de Hispanistas (pp. 105-119). Vol. 1. Bordeaux: Instituto de Estudios Ibéricos e Iberoamericanos de la Universidad de Bordeaux III.

Zavala, S. (1935). Las instituciones jurídicas en la conquista de América. Buenos Aires: Junta para Ampliación de Estudios e Investigaciones Científicas. Centro de Estudios Históricos.

Zumthor, P. (1993). La medida del mundo. Madrid: Cátedra.

\section{NOTES}

1. Con el gobierno de los Reyes Católicos, comienza además, para las élites hispanas, un proceso de resurgimiento del ideal caballeresco que se acentúa con la guerra de Granada.

2. Nos referimos, por ejemplo, a las influyentes obras de Juan Luis Vives (1492-1440), de Juan de Valdez (1509-1541), entre otros. Véase sobre este tema el capítulo "El erasmismo y la literatura profana" de Marcel Bataillon: "Fernández de Oviedo debe tener su lugar en esta rápida ojeada de 
los libros de verdad que el erasmismo español opuso a las invenciones fabulosas de los libros de caballerías." (1950, p. 642).

3. Véase el importante estudio de Irving A. Leonard (1996) sobre las ficciones que mediaron el pensamiento de la Conquista. También, el trabajo muy influyente de Enrique Pupo-Walker (1982) sobre la aprehensión imaginaria de la historiografía de las Indias y la vigencia en ella de mitos, leyendas y tópicos literarios, entre otros.

4. Libro del muy esforçado [e] inuencible Cauallero de la Fortuna propiam ete llamado don claribalte q[ue] seg u su verdadera interpretaciõ quiere dezir don Felix o bienauenturado nueuam rete imprimido [e] venido aesta lengua castellana, el qual procede por nueuo [e] galan estilo de hablarpor medio de gonçalo Fernandez de ouiedo alias de sobrepeña].

5. Cucaña consiste en un tipo de sociedad ideal que, por su exceso, era rechazada como modelo de felicidad por el pensamiento racional platónico sobreviviente en la doctrina cristiana. Describe una comunidad de comportamientos contrarios a la prudencia y la moderación. En Cucaña, hay abundancia de todas las satisfacciones: incluso, para los apetitos más brutales, tanto alimenticios como sexuales y del ocio. Que las Indias sean el "cuerno de la abundancia” es una visión que la identifica con Cucaña y que Oviedo rebatirá.

6. Por otra parte, fue muy bien estudiado por Américo Castro (1984) el crecimiento del culto a Santiago como respuesta -al estilo de musulmán- de los cristianos contra enemigos infieles.

7. En la Regla de la Orden de caballería de Santiago publicada en 1655, por ejemplo, la imagen de Felipe VI tiene en su base y como emblema la palabra "prudentia". Ubicada en ese lugar de la imagen, la palabra es una sinécdoque del Rey de las "Provincias Españolas" y del Nuevo Mundo.

8. La preocupación por la limpieza de sangre se inicia algunos años antes de 1520 con la inquietud por la mezcla entre "cristianos viejos" y judíos. El primer estatuto de limpieza de sangre en España, el famoso Sentencia Estatuto, fue legislado en Toledo en 1449. La hipótesis ampliamente demostrada por Américo Castro (1984), entre otros, es que el movimiento de exclusión que representa la consigna de limpieza de sangre fue enarbolada por las masas resentidas de conversos y descendientes de conversos ansiosos por olvidar lo que eran. Quienes traían consigo el sentimiento de escrúpulo de la limpieza de sangre no eran verdaderamente los españoles sino los judíos: encarnaban una inquietud puntillosa por la pureza familiar y el qué dirán surgidos de la nostalgia y el deseo de no perder los orígenes. Los conversos, al haber adherido a proposiciones antijudaicas y ver desvanecida su identidad de casta para alcanzar el ascenso, habrían proyectado esa misma obstinación sobre la "pureza" del linaje de los Otros: judíos "viejos", moros, herejes o recientemente convertidos.

9. David Brading (1998, p. 56) resume los acontecimientos y la situación de Oviedo en pocas palabras: "El entusiasmo de Oviedo por esta regulación [la de limpieza de sangre] (...) muestra, una vez más, hasta qué punto ésta estaba expresando la mentalidad común de los pequeños hidalgos españoles del siglo XVI".

10. Sobre la incompatibilidad entre comercio y nobleza, Antonio Domínguez Ortiz admite: “A pesar del ejemplo de las grandes ciudades mercantiles, de los centros industriales, de las plazas bancarias, en las que los 'hombres de negocio' ocupaban un puesto preeminente, la ideología renacentista, más influida por la tradición medieval de lo que suele pensarse, no acababa de digerir la figura del noble mercader; y ello, repito, no sólo en España; también en Francia (...) en Inglaterra, en la cual, según el irrecusable testimonio de Lawrence Stone, 'la ocupación personal activa del comercio o en una profesión se consideró, por lo general, humillante. El comercio al por menor siempre fue degradante, y el de Ultramar sólo era una ocupación honrosa si se dedicaban a él como afición más bien que como profesión."”. (1998, p. 194).

11. Sobre cómo Fernández de Oviedo se distancia del erasmismo también en sus ideales, aunque pretende verterlos en la construcción ejemplar de los personajes de su Historia, véase mi artículo "Pacificación y conquista en la Historia General y Natural de las Indias de Gonzalo Fernández de 
Oviedo" en revista Zama Nro. 5 del Instituto de Literatura Hispanoamericana de la Universidad de Buenos Aires.

12. Las Casas corrobora la "nobleza" de estos viajeros, pero desde un punto de vista totalmente diferente: "ocurrió toda o la más caballería, que dije perdida o gastada, a ofrecerse a Pedrarias para le acompañar y aun servir en la jornada (...) tanta es la codicia y aun liviandad de España. Rescibió mucha gente noble Pedrarias en la corte, y cuando llegó a Sevilla, halló 2.000 hombres nobles y mancebos, tan bien dispuestos, lucidos y ataviados" (Casas, L III, c 53 [MC III, p. 15-6]) El fraile asocia a esta nobleza directamente con la caballería - ya bastante criticada a mediados del siglo XVI- y con la superficialidad del buen vestir, además de con el pecado de la codicia.

13. Notablemente y como consecuencia del descubrimiento y colonización de América, crecerá una poderosa clase mercantil en Sevilla que se atreverá a traspasar los límites entre mercatura y nobleza. Más aún, en el siglo XVII, se acentuarán las concesiones nobiliarias a los residentes en Sevilla pero provenientes de distintos puntos de la península hispánica. Véase A. Domínguez Ortiz (1998).

14. La ambigüedad y la circularidad del concepto de Igualdad en Aristóteles - "hay igualdad entre los hombres iguales"- permite entender a la justicia tanto como realización de la igualdad como de la desigualdad.

15. Sobre el tema, véase Adorno 2007.

16. Sobre las probables etapas de corrección del manuscrito de la Historia, véase Kathleen Myers (2007). Si bien la primera parte del libro 26 -desde el proemio y hasta parte del capítulo 7- se encuentra perdida, es de suponer que Oviedo la corrigió extensamente hasta su muerte. Los capítulos como éste que estamos analizando, pertenecientes a las experiencias personales de Oviedo en la Tierra Firme, la Española y parte en España, están mucho más corregidos que el resto del manuscrito. "The autograph manuscript for this book [26] is not extant, but four stages of writing and revision are decipherable. They reflect not only the evolution of the conquest and the changing administrative structure in the Indies, but also Oviedo's tendency to add a more didactic frame to each chapter." (Myers, 2007, p. 59).

17. Véase Lewis Hanke (1949).

18. Aunque omite el nombre de Las Casas, lo identifica claramente al decir: "éste ya se dijo quién era, cuando se tractó de la isla de Cubagua en el libro XIX de la primera parte destas historias. (... )" (L 26, c 1 [PT III, p. 62]).

19. De hecho, Las Casas en su Historia de las Indias es totalmente indiferente a esta propuesta de Oviedo, aunque dedica muchas páginas a ironizar y polemizar con él sobre los temas de Indias.

20. Armando Pavón Romero advierte, sin embargo, que, a medida que el Imperio fue expandiéndose, fue perdiendo también capacidad de control y sujeción: "Las colonias quedaron sujetas a la metrópoli más por una compleja red de relaciones económicas, sociales, culturales, simbólicas y de otros tipos, pero no por una efectiva capacidad de sujeción, al grado de que en la Nueva España no se contó con un ejército regio sino hasta el siglo XVIII." (2008, p. 337). Erasmo de Rotterdam (2007) ya había advertido al príncipe: para el buen gobierno, se debe estar cerca y conocer los reinos que se encuentran bajo su soberanía.

21. Existe una larga y reconocida tradición de identificación del monarca -gobernador o capitán de una nave- con su reino o ciudad. Pero, para los lectores de hoy, esta relación no es tan evidente ni transparente. Sobre el tema, véanse los ensayos de Lewis Mumford, especialmente "La utopía, la ciudad y la máquina", en donde detalla claramente este vínculo, aparecido ya en la cultura egipcia en la que la ciudad fue, ante todo, un fenómeno religioso y la morada de un dios; al contrario de los meros caseríos, aldeas y villas rurales aisladas y "pegadas" a la tierra. El rey representa o encarna, como en Egipto, el poder divino y la vida comunal que se concentran de manera visible en la ciudad. (Mumford, 1982, p. 42). 
22. Véase "Gonzalo Fernández de Oviedo y la incipiente conciencia criolla en la historiografía de Indias" de Sarah H. Beckjord (2009). Esta autora ha analizado el afán de Oviedo de "ser señor" en las Indias.

23. De la visión negativa de Oviedo sobre las modalidades de trueque de los indios, se desprenden también sus valoraciones acerca de las actitudes mercantiles de los españoles. Por ejemplo: "Era ejercicio principal de los indios de esta isla Haití o Española (...) mercadear e trocar unas cosas por otras, no con la astucia de nuestros mercaderes, pidiendo por lo que vale un real muchos más, ni haciendo juramentos para que los simples los crean, sino muy al revés de todo esto y desatinadamente." (L 5, c 3 [PT I, p. 123]).

24. Cortés, en sus cartas de relación al Monarca, por ejemplo, narra con detalle los sacrificios "espectaculares" y "ejemplares" de los cautivos españoles por parte de los mexicas previos a la huida en la Noche Triste.

25. Álvaro Bolaños sostiene que Oviedo construye una autoglorificación en claro contraste con las figuras de Pedrarias y de Simón Bernal: “Oviedo apunta a la cobardía de Bernal (ya expresada con su aproximación por la espalda) al valerse de un arma innoble a pesar de portar una espada. El valor de esta mención de las armas es notorio más adelante cuando Oviedo nos indica que él sí recurre a la espada en sus esfuerzos por defenderse: 'e dándome priesa a levantarme, dije: "Oh traidor, por qué me has muerto?” E puse mano a la espada, que tenía ceñida' (277)” (Bolaños, 1990, p. 597).

26. "Existen conductas espontáneas de imitación, lo que, con frecuencia, ha llevado a considerar que la tendencia a la imitación es un instinto, y de una importancia capital a los ojos del sociólogo. Por otra parte, es conocido el lugar atribuido por la psicología contemporánea a los procesos de identificación. (...) Si la referencia a un modelo permite promover ciertas conductas, la referencia a un contraste, a un antimodelo, posibilita su alejamiento." (Perelman, 1995, p. 57).

27. Según este autor: "El retorno del oprimido, esos aterrorizantes estereotipos de salvajismo, canibalismo, lascivia y anarquía, son los puntos que señalan la identificación y la alienación, escenas de miedo y deseo, en los textos coloniales. Es precisamente esta función del estereotipo como fobia y fetiche la que, de acuerdo con Fanon, amenaza la clausura del esquema racial/ epidérmico para el sujeto colonial, y abre la vía regia a la fantasía colonial". (Bhabha, 2002, p. 98).

28. Sobre el tema de lo que en la época se consideró la "inevitable" esclavitud de los indios, véase La Patria del Criollo de Severo Martínez Peláez (1998), que analiza específicamente el caso de la colonia guatemalteca.

29. El significado de "manceba" según el Tesoro de la lengua castellana o española es el siguiente: "este termino se toma siempre en mala parte, por la muger soltera que tiene ayuntamiento con hombre libre, porque esto suele comunmente acontecer entre moços y moças: pero confundese la sinificacion estendiendose a sinificar cualquiera ayuntamiento que no sea legitimo, quando es continuado." (Covarrubias, 1611, p. 1097).

30. Lewis Mumford: "Los cuarteles militares, en el orden barroco, ocupan casi el mismo lugar que el monasterio en el medieval; y los campos de desfile -como el nuevo Champ de Mars en París, por ejemplo- eran tan notorios en las nuevas ciudades como el propio Marte lo fuera en la pintura renacentista" (1982, p. 499). 


\section{ABSTRACTS}

In this paper, I plan to look into two different proposals for the colonization of Central America -which were founding to Spanish colonization policies throughout Spanish America- from a paradigmatic writer of the American Conquest: Gonzalo Fernández de Oviedo, who was the Cronista Oficial of the Indies for the Spanish Crown during the first half of the XVIth century. This paper reveals and analyzes the Historia General y Natural de las Indias, that reproduces some of the king's capitulations and other implicit proposals in its edifying historiographic speech. A first project, presented to and rejected by the king, proposed the transferal of noble knights who carried out "orderly" conquests in the Indies; the other, implied in the historiographic speech, pursued a model of colonial city that replicated the social forms of the Spanish metropolis. We shall trace, in this manner, certain utopian images of the New World, such as the Castilian noble hidalgo knight, the endeavor for blood "cleanliness", the hierarchical societies, the exemplar conquistadores and the cities of control, order, repression and exclusion of otherness and crossbreeding. Methodologically, the focus of analysis is interdisciplinary: by means of Colonial Studies of History and Speech.

En este trabajo, investigo dos propuestas de colonización para Centroamérica -fundantes para la política de colonización española de toda Hispanoamérica - de un escritor paradigmático de la Conquista Americana: Gonzalo Fernández de Oviedo, quien fue el Cronista Oficial de Indias de la Corona española durante toda la primera mitad del siglo XVI. El artículo releva y analiza la Historia General y Natural de las Indias, que contiene reproducidas algunas capitulaciones del rey y otras propuestas implícitas en su discurso historiográfico edificante. Un primer proyecto, presentado y rechazado por el rey, se proponía el traslado de caballeros nobles que llevasen en las Indias conquistas "ordenadas"; el otro, implícito en el relato historiográfico, perseguía un modelo de ciudad colonial que fuese réplica de las formas sociales de la metrópoli española. Rastreamos, así, ciertas imágenes utópicas de Oviedo sobre el Nuevo Mundo, tales como la del noble caballero hidalgo castellano, la procuración de "limpieza" de sangre, las sociedades jerárquicas, los conquistadores ejemplares y las ciudades del control, el orden, la represión y la exclusión de la otredad y el mestizaje. Metodológicamente, el enfoque de análisis es interdisciplinario: abordamos el corpus desde los métodos e intereses de los Estudios Coloniales de la Historia y del Discurso.

\section{INDEX}

Keywords: Key words: Gonzalo Fernández de Oviedo, Indies, Conquest, colonization, New World utopias.

Palabras claves: Palabras clave: Gonzalo Fernández de Oviedo, Indias, - Conquista- colonizaciónutopías del Nuevo Mundo 


\section{AUTHOR}

VANINA MARÍA TEGLIA

UBA- FFyL- Instituto de Literatura Hispanoamericana. Correo electrónico: vaninateglia@filo.uba.ar 